\title{
Why Courts Cannot Deny ADA Protection to Plaintiffs Who Do Not Use Available Mitigating Measures for Their Impairments
}

\author{
Sarah Shaw †
}

\section{TABLE OF CONTENTS}

Introduction

I. Legal Background: The Americans with Disabilities Act

A. Definition of "Disability"

B. Definition of "Qualified Individual".

C. Exceptions to the Eniployer's Duty of Reasonable Accommodation.

II. Emergence and Persistence of the "Failure to Control a Controllable Disability" Doctrine

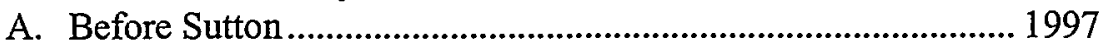

1. Cases Implicating Causation and Qualification ................. 1998

2. Cases Implicating the Disability Definition ....................... 2002

B. Analysis of Sutton and Its Implications for Lower Courts ....... 2004

1. Speculation Regarding the Effectiveness of Treatment ..... 2008

2. Speculation Regarding the Side Effects of Treatment ....... 2010

3. Speculation Regarding the Plaintiff's Ability to Conıply with Treatment

C. After Sutton: The Ongoing Denial of ADA Coverage to

Nonmitigating Plaintiffs

1. The Continued Role of Speculation in the "Disability" Determination.

Copyright (C) 2002 California Law Review, Inc. California Law Review, Inc. (CLR) is a California nonprofit corporation. CLR and the authors are solely responsible for the content of their publications.

$\dagger \quad$ J.D., School of Law, University of California, Berkeley (Boalt Hall), 2002; B.S., Tufts University, 1994. 1 wish to thank California Law Review editors Heather Rosmarin and Sam Weinstein for their valuable assistance with this Comment. Early drafts also benefited significantly from the suggestions offered by Professor Linda Krieger. Any mistakes are, of course, my own. 1 would also like to thank other California Law Review members and editors who helped prepare this Comment for publication, including Sarah Abbott, Jason Bezis, Jennifer Conners, Sarah Cunningham, Lisa Delehunt, Nick Dierman, Mara Krongard, Donna Maeda, Matt McDermott, and Heather Weaver. Finally, special thanks to Jeffery Eddings, Zoe Lampros, and Stan Shaw for their assistance and support throughout this project. 
2. Reliance on a Broad Interpretation of Siefken 2016

3. The Prohibition on Speculation as a New Justification for Denying ADA Protection

III. Analysis of the Statute's Language, History, and Structure. 2018

A. Congressional Intent 2019

B. Existing Law Is Sufficient to Protect the Interests of

Employers and Employees Who Decide to Mitigate 2020

1. Restrictions and Exemptions that Protect the Interests of Employers

a. The "Qualified Individual with a Disability"

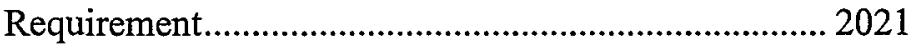

b. The "Direct Threat" Provision..................................... 2022

c. Misconduct that Severs the Causal Link Between Disability and Discrimination

2. Individuals Who Mitigate Their Impairments Are Protected by the "Record of" and "Regarded as" Definitions.

IV. Critique of Proposals that Courts Should Evaluate the Reasonableness of a Plaintiff's Decision Not to Mitigate.

A. Balancing the Plaintiff's Burden of Mitigation Against the Employer's Burden of Accommodation

B. Insertion of an Employee-Focused Reasonableness Test into the Statute's Reasonable Accommodation Requirement... 2030

1. The Proposed Reasonableness Test..................................... 2030

2. Courts' Lack of Statutory Authority to Implement an Employee-Focused Reasonableness Test 2033

3. Considerations Weighing Against Congressional Enactment of the Proposed Reasonableness Test.

a. Problems with Second-Guessing the Personal

Medical Decisions of Disabled Individuals 2040

b. Inappropriateness of the Tort Doctrine of Avoidable Consequences in the ADA Context 2043

c. Line-drawing Problems and the Failure of "Easy" Cases to Justify the Proposed Rule 2043

Conclusion 2045 


\title{
Why Courts Cannot Deny ADA Protection to Plaintiffs Who Do Not Use Available Mitigating Measures for Their Impairments
}

\author{
Sarah Shaw
}

Congress intended the Americans with Disabilities Act ("ADA") to provide strong standards for addressing and eliminating discrimination against individuals with disabilities. Many commentators have concluded, however, that the federal courts are undermining the goals of the ADA by too narrowly construing membership in the statute's protected class. One example of this trend is courts' hostile treatment of ADA plaintiffs who do not use medications or devices that might alleviate their impairments ("nonmitigating plaintiffs"). Numerous district and appellate decisions have held or suggested that nonmitigating plaintiffs are not protected by the ADA. In addition, some commentators have proposed that courts should evaluate the reasonableness of a plaintiff's decision not to use mitigating measures; they argue that it is unfair to burden an employer with the cost of accommodating a disability that continues to exist only because an employee unreasonably refuses to mitigate it. Contrary to the views of these courts and commentators, however, this Comment will show that nonmitigating plaintiffs are entitled to ADA protection from employment discrimination. It argues that the statute's language, history, and structure, as well as Supreme Court precedent, demonstrate that courts cannot deny ADA protection based on a plaintiff's nonuse of available mitigating measures. It also presents several considerations that weigh against any future congressional enactment that would tie ADA protection to the reasonableness of a plaintiff's decision not to mitigate an impairment.

\section{INTRODUCTION}

The Americans with Disabilities Act (the "ADA" or "Act") forbids most employers from discriminating against a "qualified individual with a 
disability" on the basis of that individual's disability. ${ }^{1}$ Many commentators have concluded, however, that the federal courts are undermining the goals of the ADA by too narrowly construing membership in the statute's protected class. ${ }^{2}$ This Comment focuses on courts' hostile treatment of ADA plaintiffs who do not use medications or devices that might alleviate their impairments ("nonmitigating plaintiffs"). Courts have been particularly hostile to nonmitigating plaintiffs. Numerous district and appellate decisions have held or suggested that nonmitigating plaintiffs are not covered by the $\mathrm{ADA} .{ }^{3}$ This Comment will show that, to the contrary, nonmitigating plaintiffs are entitled to $\mathrm{ADA}$ protection from employment discrimination.

There are many reasons why an ADA plaintiff might not use available mitigating measures. A plaintiff might refuse such measures because they have serious side effects or because the treatment will require a lifestyle change that the plaintiff is unwilling to make. Alternatively, the symptoms of a plaintiff's disability might make it difficult to comply with prescribed treatment. For example, individuals suffering from schizophrenia may forget to take their medication because the disorder causes disorganized thinking. ${ }^{4}$ In other situations, plaintiffs may have subjective fears about treatment, such as a strong fear of surgery, which lead them to resist available corrective measures.

As this Comment will demonstrate, the statute does not provide a basis for excluding nonmitigating plaintiffs from ADA protection. Further, there is compelling evidence that Congress intended nonmitigating plaintiffs to fall within the scope of the ADA. Courts denying protection to nonmitigating plaintiffs thus have been unable to ground their decisions in the language or legislative history of the ADA. Instead, these courts have

1. 42 U.S.C. $\S 12112$ (Title 1) (1994); id. $\$ 12132$ (Title 11). The ADA is divided into five titles. Title 1 and Title II address discrimination in the employment context. For a description of which employers are covered by the Act, see infra notes 26-27 and accompanying text.

2. See, e.g., Chai R. Feldblum, Definition of Disability Under Federal Anti-Discrimination Law: What Happened? Why? And What Can We Do About It?, 21 Berkeley J. EMP. \& LAB. L. 91, 139-60 (2000); Linda Hamilton Krieger, Foreword-Backlash Against the ADA: Interdisciplinary Perspectives and Implications for Social Justice Strategies, 21 Berkeley J. EMP. \& LAB. L. I, 7-8 (2000); see also Lisa Eichhorn, Applying the ADA to Mitigating Measures Cases: A Choice of Statutory Evils, 31 ARiz. ST. L.J. 1071, 1071 (1999); Steven S. Locke, The Incredible Shrinking Protected Class: Redefining the Scope of Disability Under the Americans with Disabilities Act, $68 \mathrm{U}$. CoLo. L. Rev. 107, 108-09 (1997).

3. See infra Part II (discussing Burroughs v. Springfield, 163 F.3d 505 (8th Cir. 1998); Van Stan v. Fancy Colours \& Co., 125 F.3d 563 (7th Cir. 1997); Siefken v. Village of Arlington Heights, 65 F.3d 664 (7th Cir. 1995); Brookins v. Indianapolis Power \& Light Co., 90 F. Supp. $2 d 993$ (S.D. Ind. 2000); Tangires v. Johns Hopkins Hosp., 79 F. Supp. 2d 587 (D. Md. 2000); Bowers v. Multimedia Cablevision, Inc., No. CIV.A.96-1298, 1998 WL 856074 (D. Kan. Nov. 3, 1998); Testerman v. Chrysler Corp., No. CIV.A.95-240, 1997 WL 820934 (D. Del. Dec. 30, 1997); Pangalos v. Prudential Ins. Co. of Am., No. 96-0167, 1996 WL 6I2469 (E.D. Pa. Oct. 15, 1996)).

4. See infra text accompanying notes 197-00. 
fashioned a novel "failure to control a controllable disability" doctrine ${ }^{5}$ to express their distaste for ADA plaintiffs who have not, in their view, engaged in appropriate self-help before requesting special accommodations from their employers. Not only is this doctrine inconsistent with the language and legislative history of the statute, it conflicts with the Supreme Court's view of how eligibility for ADA coverage should be determined.

While the recent Supreme Court case of Sutton v. United Air Lines, Inc. ${ }^{6}$ did not directly address the issue of nonmitigating plaintiffs, its reasoning provides an analytical framework that courts must heed. ${ }^{7}$ The Sutton Court resolved a circuit split regarding the proper way to evaluate the disabilities of individuals who voluntarily use mitigatimg measures such as medications or corrective devices ("mitigating plaintiffs"). In Sutton, the plaintiffs, who suffered from severe visual myopia, asserted that they had a "disability" within the meaning of the ADA even though their vision was $20 / 20$ or better when they wore lenses. In addressing this issue, the Court emphasized that the ADA requires an individualized inquiry into whether a person has an eligible disability and that evaluating the eligibility of mitigating plaintiffs based on their "uncorrected or unmitigated state" conflicts with this mandated individual inquiry. ${ }^{8}$ The Court reasoned that if courts and employers were permitted to "speculate" about the unmitigated condition of plaintiffs who currently use mitigating measures, they would often be forced to "make a disability determination based on general information about how an uncorrected impairment usually affects individuals, rather than on the individual's actual condition." For this and other reasons, the Court held that the determination of ADA coverage must be based on a plaintiff's present condition, taking into account drugs or devices that a plaintiff uses to mitigate the effects of her impairment. ${ }^{10}$ Under Sutton, courts may find that an ADA plaintiff who successfully uses such mitigating measures is no longer sufficiently impaired to qualify for $\mathrm{ADA}$ protection. ${ }^{11}$

The reasoning of the Sutton Court has important implications for nonmitigation cases. Significantly, for a court to conclude that a nonmitigating plaintiff would not be disabled if she used available

5. The quoted phrase first appeared in the holding of Siefken, 65 F.3d at 667, and has been repeated by some other courts that denied ADA coverage to plaintiffs who did not use available mitigating measures. See, e.g., Burroughs, 163 F.3d at 509 (adopting the language of the Siefken holding as its own holding); Brookins, $90 \mathrm{~F}$. Supp. 2d at 1006 (quoting the Siefken holding).

6. 527 U.S. 471 (1999).

7. See infra Part II.B (discussing the Sutton case and its implications for nonmitigating plaintiffs).

8. 527 U.S. at 483.

9. Id.

10. Id. at 482 .

11. Id. at 488 (concluding that the plaintiffs did not qualify for ADA protection because their use of corrective lenses rendered them functionally identical to individuals who had perfect vision). 
mitigating measures, the court would have to engage in speculation. For example, the court would have to speculate that treatment would be effective for the particular plaintiff, that the side effects of the treatment would not be disabling for the particular plaintiff, and that the symptoms of the particular plaintiff's disability would not prevent her from complying with treatment. As Sutton made clear, the ADA prohibits such speculation because it would require courts to evaluate a particular plaintiff based on the characteristics of a group of people with similar impairments rather than as an individual, thereby contradicting the individualized inquiry mandated by the statute. ${ }^{12}$ Thus, Sutton implies that if a plaintiff does not use mitigating measures, her impairment must be evaluated in its present unmitigated state (as opposed to a hypothetical mitigated state). An obvious corollary is that lower courts should not deny ADA coverage based on a belief that a nonmitigating plaintiff would not be disabled if she used available mitigating measures.

Since Sutton was decided, at least one district court has correctly applied its logic and refused to engage in a speculative analysis of whether a plaintiff would have qualified for ADA protection had she used a hearing aid. ${ }^{13}$ However, other courts have continued to deny ADA protection based on an individual's failure to use allegedly appropriate mitigating measures. ${ }^{14}$ In addition to critiquing these court decisions, this Comment refutes the main arguments and proposals that have been advanced by commentators who would deny ADA protection to nonmitigating plaintiffs. These commentators seem determined to craft a legal rationale for penalizing an $\mathrm{ADA}$ plaintiff who has not engaged in the allegedly requisite amount of self-help before seeking help from society. One set of commentators has explicitly used Sutton's prohibition on speculation as a new justification for denying ADA coverage to plaintiffs who do not mitigate their disabilities. They suggest that a plaintiff who does not follow her prescribed treatment regimen should be summarily denied ADA protection if her functioning in a properly mitigated state cannot be evaluated without speculation. ${ }^{15}$ Another set of commentators has relied on Sutton to support a new balancing test in ADA cases. Under this test, if the burden of reasonable accommodation on the employer outweighs the burden of mitigation on the plaintiff, then the employer should be relieved of its duty of

12. Id. at $482-83$.

13. See Finical v. Collections Unlimited, Inc., 65 F. Supp. 2d 1032, 1037-38 (D. Ariz. 1999).

14. See infra Part II.C.1-2 (discussing Tangires v. Johns Hopkins Hosp., 79 F. Supp. 2d 587 (D. Md. 2000) and Brookins v. Indianapolis Power \& Light Co., 90 F. Supp. 2 d 993 (S.D. Ind. 2000)).

15. See infra Part II.C.3 (discussing the proposal set forth in Perry Meadows \& Richard A. Bales. Using Mitigating Measures to Determine Disability Under the Americans with Disabilities Act, 45 S.D. L. REv. 33, 54-55 (2000)). 
accommodation. ${ }^{16}$ Yet another proposal, which was published before Sutton but is still influential, would require courts to apply an employeefocused "reasonableness" test. ${ }^{17}$ Under this approach, an accommodation is not "reasonable" if an individual with a disability does not take steps "that an ordinarily prudent person would take under the circuunstances in an effort to better his condition." 18

The persistence with which courts and commentators seek to deny ADA protection to individuals who do not use available mitigating measures is alarming for several reasons. First, the willingness of many of these courts and commentators to speculate about a plaintiff's functioning in a hypothetical mitigated state arguably reflects the very "stereotypic assumptions" that the ADA was intended to combat. ${ }^{19}$ By purporting to know that a treatment will be effective in the plaintiff's particular case, that it will not lead to disabling side effects, and that the plaintiff will be capable of complying with the prescribed treatment, these courts and commentators oversimplify the situations of individuals with disabilities. Further, they discount the legitimacy of subjective fears that might motivate an individual to decline available treatment. This dismissive attitude reinforces the view of the disabled individual as a deviant, despite the fact that medical evidence suggests that irrational noncompliance with medical treatment regimens is commonplace in the general population. ${ }^{20}$

In sum, this Comment will demonstrate that an ADA plaintiff's claim cannot and should not fail solely because she has declined available mitigating measures. The next section (Part I) presents relevant legal background on the ADA. Part II begins by tracing the development of the "failure to control a controllable disability" doctrine prior to Sutton. It then explains Sutton's prohibition on speculation and presents empirical evidence to show that a court cannot evaluate a plaintiff's impairment in a

16. See infra Part IV.A (discussing the proposal set forth in Debra Burke \& Malcolm Abel, Ameliorating Medication and ADA Protection: Use It and Lose It or Refuse It and Lose It, 38 AM. Bus. L.J. 785, 813-17 (2001)).

17. See infra Part IV.B (discussing the proposal advanced in Lisa E. Key, Voluntary Disabilities and the ADA: A Reasonable Interpretation of "Reasonable Accommodations", 48 HASTINGS L.J. 75, 96-103 (1996)). Although published before Sutton, this proposal is still influential because several postSutton commentators have made similar suggestions. See, e.g., Burke \& Abel, supra note 16, at 813 (including the reasonableness of an employee's decision not to use mitigating measures as a factor in their balancing test); Stephanie A. Fishman, Individuals with Disabilities but Without Mitigating Measures, 46 WAYNE L. REV. 2013, 2033-41 (2000) (contending that a nonmitigating plaintiff is not protected by the ADA unless she can provide a substantial justification for not using available corrective measures). In addition, some might argue that Key's proposal sidesteps the implications of Sutton by focusing on the concept of reasonable accommodation rather than the deflnition of disability, and by limiting the amount of speculation involved according to the well-established parameters of the doctrine of avoidable consequences.

18. Key, supra note 17 , at 99 .

19. 42 U.S.C. $\$ 12101(a)(7)(1994)$.

20. See infra text accompanying notes 201-04. 
hypothetical mitigated state without engaging in speculation. Finally, Part II demonstrates how subsequent courts and commentators have misconstrued, ignored or sidestepped Sutton to continue to deny ADA claims based on a plaintiff's nonuse of mitigating measures. To buttress the Sutton analysis, Part III first analyzes the Act's langnage and history to show that there is no statutory justification for denying an ADA plaintiff's claim solely because she did not use available mitigating measures. Part III then demonstrates that there is no need for a "failure to control a controllable disability" doctrine since the ADA already provides courts with multiple tools to protect the interests of employers. Part III also explains that ADA coverage of nonmitigating plaintiffs need not affect a disabled individual's incentives to mitigate her condition because individuals who successfully use mitigating measures can still receive ADA protection after Sutton. Part IV discusses and refutes several proposals advanced by commentators that would change the law by incorporating the "reasonableness" of a plaintiff"s decision not to use mitigating measures into the statute's concept of "reasonable accommodation."

\section{Legal BaCkground: The Americans With Disabilities Act}

The ADA was intended "to provide clear, strong, consistent, enforceable standards addressing discrimination against individuals with disabilities."21 It reflects congressional acknowledgement that "historically, society has tended to isolate and segregate individuals with disabilities, and, despite some improvements, such forms of discrimination against individuals with disabilities continue to be a serious and pervasive social problem." 22 In enacting the $\mathrm{ADA}$, Congress recognized that discrimination against the disabled not only takes the form of "outright intentional exclusion," but that the effects of "architectural, transportation, and communication barriers" designed to cater to the needs of the non-disabled majority can also be discriminatory. ${ }^{23}$ The Act states that "the Nation's proper goals regarding individuals with disabilities are to assure equality of opportunity, full participation, independent living, and economic self-sufficiency." 24

21. 42 U.S.C. $\S 12101(b)(2)(1994)$. This is one of the four purposes of the Act that is expressly stated in its opening section.

22. Id. $\S 12101(\mathrm{a})(2)$. This is one of the nine congressional findings presented in the opening section of the Act.

23. Id. $\S 12101(\mathrm{a})(5)$. See also John M. Vande Walle, Comment, In the Eye of the Beholder: Issues of Distributive and Corrective Justice in the ADA's Employment Protection for Persons Regarded as Disabled, 73 CHI.-KENT L. Rev. 897, 929 (1998) (discussing the legislative history of the ADA).

24. 42 U.S.C. $\$ 12101(\mathrm{a})(8)$ (1994). This is one of the nine congressional findings presented in the opening section of the Act. 
To achieve its goals, the Act expanded legal protection against employment discrimination for disabled individuals to most public and private employment settings. ${ }^{25}$ Title I of the ADA covers most employers, including private employers with more than fifteen employees and public employers such as state and local governments. ${ }^{26}$ Title II of the ADA generally prohibits disability discrimination by state and local governments, including employment discrimination. ${ }^{27}$ All of the lower court cases that are discussed in this Comment were brought under Title $\mathrm{I}^{28}$ Therefore, this background section will focus on Title I.

Title I of the ADA prohibits covered einployers from discriminating against "a qualified individual with a disability" because of the disability of

25. Prior to the enactment of the ADA, the most comprehensive federal legislation prohibiting disability discrimination by employers was the Rehabilitation Act of 1973. See Stephanie Proctor Miller, Comment, Keeping the Promise: The ADA and Employment Discrimination on the Basis of Psychiatric Disability, 85 CALIF. L. REv. 701, 704 (1997). The Rehabilitation Act only covered federal executive agencies, federal contractors, and entities receiving federal financial assistance. Robert $\mathrm{E}$. Rains, A Pre-History of the Americans with Disabilities Act and Some Initial Thoughts as to its Constitutional Implications, 11 ST. Louis U. PUB. L. REv. 185, 190 (1992). The drafters of the ADA and its associated regulations borrowed extensively from the Rehabilitation Act. See Miller, supra, at 703 (noting that ADA terminology such as "qualified individual with a disability," "reasonable accommodation," and "undue hardship" are taken directly from the Rehabilitation Act). For this reason, it is often appropriate to look to Rehabilitation Act regulations and precedent for guidance when interpreting ADA provisions that are substantially similar. See, e.g., Bragdon v. Abbott, 524 U.S. 624, 633-39 (1998) (referring to Rehabilitation Act regulations to decide whether reproduction constitutes a major life activity); Vande Zande v. Wis. Dep't of Admin., 44 F.3d 538, 542 (7th Cir. 1995) (stating that decisions interpreting terms in Rehabilitation Act regulations can be used to determine the meaning of the same terms in the ADA). Congress has expressly provided that the ADA should not be construed to provide lesser standards than those applied under Title $\mathrm{V}$ of the Rehabilitation Act and its accompanying regulations. See 42 U.S.C. $\$ 12201$ (a) (1994). However, it should be noted that there are several respects in which the ADA differs from the Rehabilitation Act, and therefore Rehabilitation Act precedent is not always an appropriate guide. See Zimmer ET. AL., CASES and Materials on EMPLOYMENT Discrimination 741 (5th ed. 2000) (noting that prior to the 1990 Rehabilitation Act amendments, some major differences between the Rehabilitation Act and the ADA were that the Rehabilitation Act did not expressly deny coverage to current users of illegal drugs, that it did not expressly permit employers to discipline employees whose current alcohol use interfered with their job performance, and that it did not expressly mention reassigument to a vacant position as a possible reasonable accommodation).

26. See 42 U.S.C. $\$ 12111(5)(A)$ (1994). Title I also covers employment agencies, labor organizations, and joint labor-management committees. Id. $\$ 12111(2)$. The United States and Indian tribes are among the employers excepted from Title I coverage. Id. $\$$ I2I I 1(5)(B).

27. See id. \$\$12131-12132.

28. See Burroughs v. Springfield, 163 F.3d 505, 507 (8th Cir. 1998); Van Stan v. Fancy Colours \& Co., I25 F.3d 563 (7th Cir. 1997); Siefken v. Village of Arlington Heights, 65 F.3d 664, 666 (7th Cir. 1995); Rose v. Home Depot U.S.A., Inc., 186 F. Supp. 2d 595, 608 (D. Md. 2002); Capizzi v. County of Placer, 135 F. Supp. 2d II05, 1 I09 (E.D. Cal. 2001); Hewitt v. Alcan Aluminum Corp., 185 F. Supp. 2d I83, 187 (N.D.N.Y. 2001); Saunders v. Baltimore County, 163 F. Supp. 2d 564, 567 (D. Md. 2001); Tangires v. Johns Hopkins Hosp., 79 F. Supp. 2d 587, 593 (D. Md. 2000); Brookins v. Indianapolis Power \& Light Co., 90 F. Supp. 2d 993, 999 (S.D. Ind. 2000); Finical v. Collections Unlimited, Inc., 65 F. Supp. 2d 1032, 1035 (D. Ariz. I999); Bowers v. Multimedia Cablevision, Inc., No. CIV.A.96-I298, 1998 WL 856074, at *4 (D. Kan. Nov. 3, 1998); Testerman v. Chrysler Corp., No. CIV.A.95-240, 1997 WL 820934, at $* 7$ (D. Del. Dec. 30, 1997); Pangalos v. Prudential Ins. Co. of Ain., No. 96-0167, 1996 WL 612469 (E.D. Pa. Oct. 15, 1996). 
such individual..$^{29}$ Thus, in order to create a prima facie case of discrimination under the ADA, a plaintiff must initially prove (1) that she has a "disability" as defined in the statute, (2) that she is "qualified" within the meaning of the statute, and (3) that the adverse employment action was taken "because of" her disability. ${ }^{30}$

\section{A. Definition of "Disability"}

The ADA requires courts to determine the existence of disabilities on a case-by-case basis. ${ }^{31}$ To this end, the Act provides three alternative definitions of disability:

The term "disability" means, with respect to an individual-

(A) a physical or mental impairment that substantially limits one or more of the major life activities of such individual;

(B) a record of such an impairment; or

(C) being regarded as having such an impairment. ${ }^{32}$

Thus, to fall within the ADA's disability definition, an individual must have a current disability, must have a record of a disability, or must be "regarded as" having a disability. ${ }^{33}$

The first definition of disability, contained in 42 U.S.C. $\S 12102(2)(\mathrm{A})$ ("Subsection A"), is sometimes referred to as the "actual disability" definition. ${ }^{34}$ This definition can be divided into three elements, each of which has been the subject of extensive regulation and litigation: (1) physical or mental impairment; (2) major life activity; and (3) substantial limitation. Although the statute itself does not define what is meant by "physical or mental impairment," "major life activities," or "substantially limits," these terms are defined in Equal Employment Opportunity Commission ("EEOC") regulations. ${ }^{35}$ Although the particular

29. 42 U.S.C. $\$ 12112(1994)$.

30. Id. Bristol v. Bd. of County Commr's, 281 F.3d 1148, 1156 (10th Cir. 2002); Dropinski v. Douglas County, 298 F.3d 704, 706 (8th Cir. 2002); Dvorak v. Mostardi Platt Assocs., Inc., 289 F. 3d 479,483 (7th Cir. 2002). The extent of the ADA plaintiff's burden regarding causation varies depending upon whether courts apply the burden-shifting pretext causation scheme of McDonnell Douglas Corp. v. Green, 411 U.S. 792 (1973), or the mixed-motive analysis of Price Waterhouse v. Hopkins, 490 U.S. 228 (1989). For the purposes of this Comment, however, it is sufficient to note that courts must consider causation to resolve an ADA claim. For a discussion of the two models of causation and their application in ADA cases, see Robert Belton, Mixed-Motive Cases in Employment Discrimination Law Revisited: A Brief Updated View of the Swamp, 51 MERCER L. REv. 661, 665-66 (2000).

31. See Albertson's, Inc. v. Kirkingburg, 527 U.S. 555, 566 (1999) (emphasizing that the text of the ADA expressly defines disability "with respect to an individual"); Sutton v. United Air Lines, Inc., 527 U.S. 471, 472 (1999) (stating that "whether a person has a disability under the ADA is an individualized inquiry").

32. 42 U.S.C. $\$ 12102(2)$ (I994).

33. Sutton, 527 U.S. at 478.

34. See e.g., id.

35. See 29 C.F.R. \$ $1630.2(\mathrm{~h})-(\mathrm{j})(200 \mathrm{I})$. 
regulatory sections defining these terms are not authoritative ${ }^{36}$ and it is unclear what level of deference they should receive, ${ }^{37}$ the EEOC regulations regarding the Act's definition of disability provide a useful set of interpretations and examples on which courts and commentators often rely. ${ }^{38}$

The EEOC regulations define a "physical impairment" as "[a]ny physiological disorder, or condition, cosinetic disfigurement, or anatomical loss affecting one or more of the following body systems: neurological, musculoskeletal, special sense organs, respiratory (imcluding speech organs), cardiovascular, reproductive, digestive, genito-urinary, hemic and lymphatic, skin, and endocrine."39 The EEOC defines "mental impairment" as "[a]ny mental or psychological disorder, such as mental retardation, organic bram syndrome, emotional or mental illness, and specific learning disabilities." 40 The EEOC explicitly excludes certain nental conditions from the definition of "disability," including transvestism, transsexualism, pedophilia, exhibitionism, voyeurism, compulsive gambling, kleptomania, pyromania, and disorders resulting from current illegal use of psychoactive drugs. ${ }^{41}$

The issue of what constitutes a major life activity has become a subject of extensive litigation. ${ }^{42}$ EEOC regulations define "major life activities" as "functions such as carmg for oneself, performing manual

36. The Supreme Court has indicated that EEOC regulations concerning the definition of "disability" are not authoritative because the ADA's definition of disability is contained in a general definitional section of the Act that falls outside of Title I, whereas the EEOC's statutory authority to issue regulations is limited to the provisions contained in Title I. See Sutton, 527 U.S. at 479.

37. After observing that no agency has been given authority to issue regulations implementing the generally applicable provisions of the ADA (\$\$ I2I01-12I02), the Sutton Court cited the EEOC's definitions of "physical impairment," "substantially limits," and "major life activities," and then stated that "[b]ecause both parties accept these regulations as valid, and determining their validity is not necessary to decide this case, we have no occasion to consider what deference they are due, if any." Id. at 479-80. See also Capizzi v. County of Placer, I35 F. Supp. 2d I105, 1110 (E.D. Cal. 200I) (noting that the Sutton Court did not determine whether EEOC regulations and guidelines, while not binding, are still entitled to deference).

38. See, e.g., Sutton, 527 U.S. at 501-02 (Stevens, J., dissenting) (stating that EEOC interpretations of the Act's disability definition form "a body of experience and informed judgment" that may properly be consulted for additional guidance); Capizzi, I35 F. Supp. 2d at I1I1 (concluding that until directed otherwise, it is appropriate for district courts to continue to give deference to the EEOC's definition of major life activities); Eichhorn, supra note 2, at 1085-86 (citing EEOC definitions of "physical or mental impairment," "major life activity" and "substantially limits"); Meadows \& Bales, supra note I5, at 36-37 (citing EEOC definitions of "physical or mental impairment" and "major life activity").

39. 29 C.F.R. $\$ 1630.2$ (h)(1) (2001).

40. Id. $\$ 1630.2(\mathrm{~h})(2)$.

4I. Id. $\$ 1630.3(\mathrm{~d})$.

42. See, e.g., Amir v. St. Louis Univ., 184 F.3d 1017, 1027 (8th Cir. 1999) (stating that eating, drinking, and learning are major life activities, but getting along with others may not be); Pack v. Kmart Corp., I66 F.3d 1300, 1305 (I0th Cir. I999) (holding that sleeping is a major life activity, but concentrating is not); Reeves v. Johnson Controls World Servs., Inc., 140 F.3d I44, 147 (2d Cir. 1998) (holding that the plaintiff's panic disorder with agoraphobia was not disabling because "everyday mobility" is not a major life activity). 
tasks, walking, seeing, hearing, speaking, breathing, learning, and working. ${ }^{43}$ However, the Supreme Court has indicated that this list is both overinclusive $^{44}$ and underinclusive. ${ }^{45}$

Courts have also struggled with the meaning of the term "substantially limits." EEOC regulations suggest that an individual is substantially limited in a major life activity if the individual is "[u]nable to perform a major life activity that the average person in the general population can perform" or is "[s]ignificantly restricted" in the "condition, manner or duration" under which she can perform a particular major life activity im comparison with "the average person in the general population." 46 The regulations provide that the nature, severity, duration, and expected permanent or longterm impact of the impairment should be considered in determining whether the impairment is substantially limiting. ${ }^{47}$ The Supreme Court has recently emphasized that even when the specific disability claimed by an ADA plaintiff would "ordinarily" be substantially limiting, the plaintiff must still offer evidence that the disability is substantially limiting in her own particular case. ${ }^{48}$

The second definition of disability, contained in 42 U.S.C. $\S 12102(2)(B)$ ("Subsection B"), provides that an individual has a disability within the meaning of the statute if there is a "record of such an impairment." The "such an impairment" language refers to the impairment described in Subsection A. ${ }^{49}$ EEOC regulations, ${ }^{50}$ as well as courts ${ }^{51}$ and commentators, ${ }^{52}$ have interpreted this language to encompass not only the Subsection A definitions of physical and mental impairments, but also the requirement that such impairments substantially limit a major life activity.

Finally, the third definition of disability, contained in 42 U.S.C. $\S 12102(2)(C)$ ("Subsection C"), provides that an individual has a disability within the meaning of the ADA if she is "regarded as having such an impairment." According to EEOC regulations, this definition of disability applies when (1) the individual's impairment does not substantially limit a major life activity but is treated by an employer as substantially limiting; (2) the individual's impairment substantially limits a major life

43. 29 C.F.R. $\S, 630.2(\mathrm{i})(2001)$.

44. See Sutton v. United Air Lines, Inc., 527 U.S. 47I, 492 (1999) (noting that "there may be some conceptual difficulty in defining 'major life activities' to include work").

45. Bragdon v. Abbott, 524 U.S. 624, 639 (1998) (holding that reproduction is a major life activity even though it is not on the list of examples enumeratcd in the EEOC regulations).

46. 29 C.F.R. $\S 1630.2(j)$. Special definitions and criteria are applied when "working" is the major life activity that is alleged to be substantially limited by the disability. Id.

47. Id.

48. Albertson's, Inc. v. Kirkingburg, 527 U.S. 555, 567 (1999).

49. 42 U.S.C. $\$ 12102(2)(\mathrm{A})$-(B) (1994).

50. 29 C.F.R. $\$ 1630.2(\mathrm{k})(2001)$.

51. See, e.g., Sherrod v. Am. Airlines, Inc., 132 F.3d 1I12, 1120 (5th Cir. 1998).

52. See, e.g., Burke \& Abel, supra note I6, at 801; Eichhom, supra note 2, at 1089. 
activity only as a result of the attitudes of others toward the impairment; or (3) the individual has no impairment but is treated by an employer as having a substantially limiting impairment. ${ }^{53}$ The Supreme Court has indicated that the Subsection A definitions of "impairment," "substantially limits" and "major life activity" are incorporated into the "regarded as" definition of disability of Subsection $\mathrm{C}^{54}$

Both the Subsection B "record of" and the Subsection C "regarded as" definitions of disability reflect the drafters' sensitivity to the fact that a person who is not currently disabled may still be discriminated against if others perceive her as disabled..$^{55}$ For instance, in School Board of Nassau County v. Arline, the Court stated that the "regarded as" definition refiects congressional acknowledgement of the fact that "society's accumulated myths and fears about disability and disease are as handicapping as are the physical limitations that flow from actual impairment." ${ }^{.56}$ The Arline Court also stated that the "record of" and "regarded as" provisions reflect congressional concern with "archaic attitudes and laws" and "the fact that the American people are simply unfamiliar with and insensitive to the difficulties confront[ing] individuals with handicaps."57

\section{B. Definition of "Qualified Individual"}

The ADA defines a "qualified individual" as one who "with or without reasonable accommodation, can perform the essential functions of the employment position that such individual holds or desires." 58 Central to this definition is the relationship between the concepts of essential functions, reasonable accommodation, and discrimination. If an individual with a disability cannot perform essential functions of the employment position even with reasonable accommodation, then the employer has no duty to accommodate and may legally discriminate on the basis of disability. ${ }^{59}$ However, if an individual with a disability can perform the essential functions of the job with reasonable accommodation, then the employer

53. See 29 C.F.R. $\$ 1630.2(1)(2001)$.

54. See Sutton v. United Air Lines, Inc., 527 U.S. 471, 490-91 (1999) (stating in its discussion of the "regarded as" definition that "[a]n employer runs afoul of the ADA when it makes an employment decision based on a physical or mental impairment, real or imagined, that is regarded as substantially limiting a major life activity.") See also Feldblum, supra note 2, at 157 (stating that lower courts have tended to employ a "literalist reading" of the ADA that incorporates the Subsection A requirements into the "regarded as" definition of disability). But see Eichhom, supra note 2, at 1090 (noting that the literalist reading contradicts more expansive interpretations in the legislative history).

55. See Eichhorn, supra note 2, at 1089.

56. 480 U.S. 273, 284 (1987) (a Rehabilitation Act case). See supra note 25 for an explanation of why it is appropriate to rely on Rehabilitation Act precedents like Arline.

57. Id. at 279 (quoting S. REP. No. 93-1297, at 50 (1974)).

58. 42 U.S.C. $\$ 12111(8)(1994)$.

59. See id. $\S \S 12111(8), 12112$. 
has a duty to provide such an accommodation, ${ }^{60}$ and failure to do so amounts to illegal discrimination. ${ }^{61}$

Unlike EEOC regulations concerning the definition of "disability," EEOC regulations concerning the definition of a "qualified individual" are authoritative. ${ }^{63}$ The regulations require a court to undertake several factual inquiries to determine whether an individual is "qualified." First, the court must ask whether the plaintiff satisfies certain prerequisites of the job position, such as educational background, employment experience, and legal licenses. ${ }^{64}$ Second, the court must identify the essential functions of the job. Third, the court must identify any reasonable accommodations. Finally, the court must determine whether the plaintiff can perform the essential functions of the job with or without reasonable accommodation..$^{65}$

According to the EEOC, the term "essential functions means the fundamental job duties of the employment position" and "does not include the marginal functions of the position." of evidence that might be used to evaluate whether a particular job function is essential. For instance, they suggest that courts consider the employer's judgment regarding which functions are essential; written job descriptions prepared before advertising or interviewing job applicants; the amount of time spent performing the function on the job; and the consequences of not requiring the employee to perform the function. ${ }^{67}$ The statute itself, however, seems to place particular weight on the employer's viewpoint: it states that consideration "shall be given" to the employer's judgment regarding essential functions and to the employer's written job descriptions. ${ }^{68}$

60. ZIMMER, supra note 25 , at 807.

61. 42 U.S.C. $\S 12112(\mathrm{~b})(5)(\mathrm{A})$. This duty to provide reasonable accommodation reflects one of the unique aspects of the ADA's approach to equal opportunity for disabled employees: The ADA requires not only that disabled individuals be treated in the same way as similarly situated non-disabled individuals, but also that under certain circumstances disabled individuals must be treated differently than similarly situated non-disabled individuals. US Airways, Inc. v. Bamett, $122 \mathrm{~S}$. Ct. 1516, 1520-21 (2002); see also Krieger, supra note 2, at 4 . This requirement contrasts markedly with other antidiscrimination statutes, such as Title V1l of the Civil Rights Act of 1964, 42 U.S.C. $\S 2000$ e (1994), which require only equal treatment of similarly situated individuals. See Krieger, supra note 2, at 3.

62. See supra note 36 and accompanying text.

63. The statutory definitions of "qualified individual," "reasonable accommodation," and "undue hardship" appear in 42 U.S.C. $\$ 12111.42$ U.S.C. $\$ 12116$ empowers the EEOC to issue regulations to carry out the provisions contained in Title I ( $\$ 12111-12117)$.

64. 29 C.F.R. $\$ 1630.2(\mathrm{~m})(2001)$ (providing that the plaintiff must possess the "requisite skill, experience, education and other job-related requirements of the employment position"); Interpretive Guidance on Title 1 of the Americans with Disabilities Act, 29 C.F.R. pt. 1630, App. $\$ 1630.2(\mathrm{~m})$ (2002).

65. 29 C.F.R. $\S 1630.2(\mathrm{~m})(2001)$; 29 C.F.R. pt. 1630 , App. $\S 1630.2(\mathrm{~m})(2002)$.

66. 29 C.F.R. $\S 1630.2(\mathrm{n})(1)(2001)$.

67. Id. $\$ 1630.2(\mathrm{n})(3)$.

68. 42 U.S.C. $\$ 12111(8)(1994)$. 
"Reasonable accommodation" is defined in both the ADA itself and the associated EEOC regulations. ${ }^{69}$ The statute defines reasonable accommodation by example, although its list is illustrative rather than exhaustive. According to the statute, reasonable accommodation may include making existing facilities accessible to disabled individuals, as well as "job restructuring, part-time or modified work schedules, reassignment to a vacant position, acquisition or modification of equipment or devices, appropriate adjustment or modifications of examinations, training materials or policies, the provision of qualified readers or interpreters, and other similar accommodations for individuals with disabilities." The EEOC regulations attempt to define the concept of reasonable accommodation in broader strokes, stating that the term means "[m]odifications or adjustments to the work environment, or to the manner or circumstances under which the position... is customarily performed" and "[m]odifications or adjustments that enable a covered entity's employee with a disability to enjoy equal benefits and privileges of employment as are enjoyed by its other similarly situated employees without disabilities."71

One confusing aspect of the concept of reasonable accommodation is that it performs multiple functions in the ADA. For the purposes of this Comment, the concept of reasonable accommodation is important in four distinct ways. First, it is relevant to one of the definitions of "discrimination" provided in the statute: the failure of an employer to reasonably accommodate the known limitations of a qualified individual with a disability can constitute discrimination. ${ }^{72}$ Second, it is part of the statute's definition of a "qualified individual." 73 Third, an ADA claim will fail where a court finds that the plaintiff posed a "direct threat" to the health or safety of others in the workplace and that the threat could not be eliminated or reduced by reasonable accommodation. ${ }^{74}$ Fourth, the statute states that the failure to make a reasonable accommodation is not discrimmatory if the accommodation would impose an "undue hardship" on the operation of the employer's business. ${ }^{75}$

\section{Exceptions to the Employer's Duty of Reasonable Accommodation}

The ADA provides two exceptions to the employer's duty of reasonable accommodation: direct threat and nndue hardship. Title I defines

69. Id. \$12111(9); 29 C.F.R. $\$ 1630.2(0)(2001)$.

70. 42 U.S.C. $\$ 12111(9)(1994)$.

71. 29 C.F.R. $\S 1630.2(0)(1)($ ii)-(iii) (2001). The regulations also state that "reasonable accommodation" means "[m]odifications or adjustments to a job application process...." Id. $\$ 1630.2(0)(1)(i)$.

72. 42 U.S.C. $\S 12112(\mathrm{~b})(5)(\mathrm{A})(1994)$.

73. Id. $\$ 12111(8)$.

74. Id. $\$ 12113 ; 29$ C.F.R. $\$ 1630.2$ (r) (2001).

75. 42 U.S.C. $\$ 12112(\mathrm{~b})(5)(\mathrm{A})(1994)$. 
"direct threat" as a "significant risk to the health or safety of others that cannot be eliminated by reasonable accommodation."76 Some courts have viewed the concept of direct threat as relevant to the issue of whether an individual is "qualified" within the meaning of the statute. These courts hold or suggest that where the essential functions of the job necessarily concern the safety of others, the plaintiff bears the burden of demonstrating that she can perform those functions in a way that does not threaten the safety of others. ${ }^{77}$ Other courts view "direct threat" as an affirmative defense. According to this view, the burden is on the defendant to prove that the plaintiff posed a direct threat. ${ }^{78}$ The fact that the direct-threat provision appears in a section of the statute entitled "Defenses" supports this view. ${ }^{79}$ Under both interpretations, however, an ADA plaintiff who poses a direct threat is unlikely to prevail.

Unlike direct threat, "undue hardship" is not discussed in the "Defenses" section. ${ }^{80}$ Rather, the undue-hardship provision appears in the section of the statute that discusses the definition of discrimination. ${ }^{81}$ The statute provides that an employer may refuse to make reasonable accommodations to the known disability of a qualified individual if the employer can demonstrate that such accommodations would impose an undue hardship on the operation of its business. ${ }^{82}$ The statute defines undue hardship as "an action requiring significant difficulty or expense." ${ }^{13}$ In addition, the statute enumerates several factors that should be considered in determining whether an accommodation poses an undue hardship. ${ }^{84}$ These factors include the nature and cost of the accommodation; the impact that the accommodation will have on the facility providing it, including the effect on

76. Id. $\$ 12111(3)$.

77. See, e.g., Rizzo v. Children's World Learning Ctrs., Inc., 213 F.3d 209, 213 (5th Cir. 2000); EEOC v. Amego, Inc., 110 F.3d 135, 142-44 (1st Cir. 1997).

78. See, e.g., Nunes v. Wal-Mart Stores, Inc., 164 F.3d 1243, 1247-48 (9th Cir. 1999); EEOC v. AIC Sec. Investigations, Ltd., 55 F.3d 1276, 1283-85 (7th Cir. 1995).

79. 42 U.S.C. $\S 12113$ (1994). The section provides that "[i]t may be a defense to a charge of discrimination under [the $\mathrm{ADA}]$ that an alleged application of qualification standards ... has been shown to be job-related and consistent with business necessity, and such performance cannot be accomplished by reasonable accommodation." Id. $\S 12$ I13(a). The section further provides that "[t]he term 'qualification standards' may include a requirement that an individual shall not pose a direct threat to the health or safety of other individuals in the workplace." Id. $\S 12113(\mathrm{~b})$.

80. Id. $\$ 12113$.

81. Id. $\$ 12112(\mathrm{~b})(5)(\mathrm{A})$.

82. Id. For an explanation of how courts should allocate the burden of proof on the issues of reasonable accommodation and undue hardship, see US Airways, Inc. v. Barnett, $122 \mathrm{~S}$. Ct. 1516, 152223 (2002).

83. 42 U.S.C. $\$ 12111(10)(A)(1994)$. The stringency of judicial interpretations of this standard vary. Some courts hold that undue hardship permits an employer to escape liability only if he can prove that the accommodation will "break him" financially. See, e.g., Vande Zande v. Wis. Dep't of Admin., 44 F.3d 538, 543 (7th Cir. 1995); Barth v. Gelb, 2 F.3d 1180, 1187 (D.C. Cir. I993). In contrast, another court has held that a combination of safety risks and loss of productivity can constitute an undue hardship. See Dexler v. Tisch, 660 F. Supp. 1418, 1426-29 (D. Conn. 1987).

84. 42 U.S.C. at $\S 12 \mathrm{I} 11(10)(1994)$. 
expenses and resources; and the overall financial resources of the employer. ${ }^{85}$ However, the list of factors in the statute is not exhaustive. ${ }^{86}$

II

\section{EMERgenCE AND PERSISTENCE OF THE "FAILURe to CONTROL A Controllable Disability" Doctrine}

The "failure to control a controllable disability doctrine," which has been repeatedly used to justify the denial of ADA protection to nonmitigating plaintiffs, first appeared in a series of district and circuit court cases decided prior to the 1999 Supreme Court case of Sutton v. United Air Lines, Inc. ${ }^{87}$ Part II.A shows how these cases, taken together, suggested that the nonuse of available mitigating measures could affect every element of the plaintiff's prima facie case.

In 1999, the Supreme Court in Sutton foreclosed the use of speculation in assessing a plaintiff's disability. Sutton resolved a circuit split regarding the proper way to evaluate the disabilities of individuals who voluntarily employ such mitigating measures as medications or corrective devices. ${ }^{88}$ The Court held that the determination of whether an ADA plaintiff is "disabled" should be based on the plaintiff"s ability to function in her voluntarily mitigated state and not on a speculative assessment of her unmitigated state. ${ }^{89}$ Part II.B examines the Sutton decision, its prohibition on speculation, and its implications for plaintiffs who do not use available mitigating measures.

Finally, Part II.C discusses the reactions to Sutton by subsequent courts and by commentators. Several lower courts deciding post-Sutton nonmitigation cases have ignored the implication of Sutton's prohibition on speculation. Some commentators have had a more extreme reaction: they read Sutton to justify further restrictions on the ability of nonmitigating plaintiffs to secure ADA protection.

\section{A. Before Sutton}

There is no language in the ADA that clearly addresses the role of mitigating measures. ${ }^{90}$ Nevertheless, pre-Sutton circuit court opinions in the Seventh and Eighth Circuits and district court opinions in the Third and

85. See id.

86. The statute states only that the "factors to be considered include" the enumerated factors. Id. $\$ 12112(10)(B)$. At least one court has explicitly stated that the list of factors in the statute is not exhaustive. Lavia v. Dep't of Corrections, 224 F.3d 190, 197 n.7 (3d Cir. 2000).

87. 527 U.S. 471 (1999).

88. Id. at 477. See also Timothy S. Bland \& Thomas J. Walsh, Jr., U.S. Supreme Court Resolves Mitigating Measures Issue Under the ADA, 30 U. MEM. L. REv. 1, 10-19 (1999); Meadows \& Bales, supra note 15 , at 42.

89. 527 U.S. at 482 .

90. Meadows \& Bales, supra note 15, at 39; Eichhorn, supra note 2, at 1092. 
Tenth Circuits held or suggested that the ADA does not protect individuals who do not use available mitigating measures. ${ }^{91}$ As this Part will demonstrate, these cases failed to present a coherent legal framework for denying $\mathrm{ADA}$ coverage to plaintiffs who do not use mitigating measures. While some courts reasoned that the failure to mitigate rendered the plaintiff not disabled, others indicated that the plaintiff was not "qualified" or that the plaintiff's failure to control her disability severed the causal link between disability and discrimination. The fact that these courts developed such disparate theories is not surprising given that a mitigation requirement has no basis in the ADA and, indeed, is inconsistent with the goals of the statute.

\section{Cases Implicating Causation and Qualification}

Franklin v. U.S. Postal Service, ${ }^{92}$ a 1988 Rehabilitation Act $^{93}$ case, was the first case to indicate that a plaintiff is not protected against disability discrimination if she fails to use available mitigating measures. The plaintiff, who suffered from paranoid schizophrenia, was discharged from her employment with the U.S. Postal Service after she violently threatened public officials on three separate occasions. ${ }^{94}$ The district court found that the plaintiff's psychiatric condition was "reasonably controllable by the use of medication," but that "[f]or various reasons Plaintiff has elected from time to time not to take the prescribed medication and the various violent episodes followed thereafter." 95 The court noted a clinical psychologist's report that the plaintiff refused her antipsychotic medication because of its side effects, including the fact that it halted her menstruation, negatively affected her eyesight, and "messed up" her body. ${ }^{96} \ln$ addition, the plaintiff reported that she had not taken her medication because she had depleted her supply, and that she had not gone to the clinic to get more medication because she did not think there was anything wrong. ${ }^{97}$

The district court held that the plaintiff had not established a cause of action under the Rehabilitation Act because she had failed to prove that she was "qualified" within the meaning of the statute." There were two

91. Burroughs v. Springfield, 163 F.3d 505 (8th Cir. 1998); Van Stan v. Fancy Colours \& Co., 125 F.3d 563 (7th Cir. 1997); Siefken v. Village of Arlington Heights, 65 F.3d 664 (7th Cir. 1995); Bowers v. Multimedia Cablevision, Inc., No. CIV.A.96-1298, 1998 WL 856074 (D. Kan. Nov. 3, 1998); Testerman v. Chrysler Corp., No. CIV.A.95-240, 1997 WL 820934 (D. Del. Dec. 30, 1997); Pangalos v. Prudential Ins. Co. of Am., No. 96-0167, 1996 WL 612469 (E.D. Pa. Oct. 15, 1996).

92. 687 F. Supp. 1214 (S.D. Ohio 1988).

93. For an explanation of the relevance of Rehabilitation Act precedents to ADA cases, see supra note 25 .

94. Franklin, 687 F. Supp. at 1216.

95. Id.

96. Id. at 1217.

97. Id. at 1216.

98. Id. at 1219. 
alternative bases for this holding. First, the court held that if the plaintiff's paranoid schizophrenia was not controllable by medication, then her antisocial behavior demonstrated that she was a danger to her coworkers, and therefore she was not "qualified." Alternatively, the court held that "[a] person suffering from the condition of paranoid schizophrenia that is controllable by the ingestion of medication who does not take such medication is not "qualified." 100 In addition, the court implied that the plaintiff's failure to take her medication severed the causal link between the plaintiff's disability and her termination. "It is Plaintiff's election not to take her medication that has caused the incidents of arrest and violence and violations of law. The choice being hers, it seems difficult if not impossible to understand why the actions of the defendant should be deemed to be discriminatory." 101 Thus, the Franklin court indicated that the plaintiff could not prevail on either the qualification or the causation element because she did not take her prescribed medication.

The first ADA case to indicate that a plaintiff's failure to use available mitigating measures could foreclose an ADA claim was Siefken v. Village of Arlington Heights, ${ }^{102}$ a 1995 Seventh Circuit case. In Siefken, the plaintiff police officer suffered a severe diabetic reaction while on duty. The reaction caused disorientation and memory loss, which in turn led him to drive his squad car at high speeds through a residential area outside his jurisdiction. According to the court, the diabetic reaction resulted from Siefken's failure to monitor his diabetes properly. Although Siefken's employer had knowledge of his diabetes when it hired him, the court specifically noted the employer's belief that Siefken could adequately perform his duties as a police officer by monitoring his diabetes. Siefken had never requested accommodations for his diabetes from his employer, and his termination letter expressly stated that the termination was due to his failure to monitor his disease. ${ }^{103}$

Although the Siefken court acknowledged the plaintiff's argument that "but for" his diabetes the incident leading to his termination would not have occurred, the court stated that the more immediate cause of Siefken's termination was his failure to adequately monitor his disease.$^{104}$ To support this view, the court cited empirical evidence that current technology and proper mountoring can reduce the chances of severe diabetic reactions to zero. ${ }^{105}$ Thus, according to the court, Siefken could not "bootstrap his

99. Id.

100. Id.

101. Id. at 1218 .

102. 65 F.3d 664 (7th Cir. 1995).

103. Id. at 665-66.

104. Id. at 666 .

105. Id. 
disease into the line of causation." 106 This aspect of the opinion indicates that the Siefken court analyzed the plaintiff's failure to control his diabetes as a proximate causation issue.

Despite this emphasis on causation, the language of the court's holding suggests that Siefken's case also failed because he was not "qualified" within the meaning of the ADA. The court stated that "[w]e only hold that when an employee knows that he is afflicted with a disability, needs no accommodation from his employer, and fails to meet 'the employer's legitimate job expectations' due to his failure to control a controllable disability, he cannot state a cause of action under the ADA."107 The emphasis on "legitimate job expectations" suggests that the court was concerned with whether Siefken was qualified to perform the essential functions of his job. ${ }^{108}$

Using an analysis similar to that of the Siefken court, the Eighth Circuit's opinion in Burroughs v. Springfield focused on causation, despite the fact that some aspects of the opinion also seemed to raise the issue of whether the plaintiff was "qualified." ${ }^{109}$ Like Siefken, Burroughs involved a diabetic police officer who initially assured his employer that his condition was under control but who was later terminated after experiencing diabetic episodes while on duty. ${ }^{110}$ The Burroughs court expressly stated that it would not discuss whether the plaintiff was "disabled" or "qualified" because the parties did not dispute those elements of the case. ${ }^{111}$ Thus, the court's discussion of the plaintiff's failure to control his diabetes purportedly concerned only causation. According to the court, "the dispute here centers on whether the City took the adverse employment action 'because of' Burroughs' disability." 12 The Burroughs court emphasized the fact that the plaintiff's disability was controllable and adopted the exact wording of the Siefken holding as its own. ${ }^{113}$

Because the Burroughs court adopted the "legitimate job expectations" language of the Siefken holding, its analysis arguably implicated the issue of whether the plaintiff was "qualified," even though the opinion said otherwise. Indeed, the Burroughs court discussed the employer's "legitimate expectations" in more detail than the Siefken court:

106. Id.

107. Id. at 667.

108. Cf. Keoughan v. Delta Airlines, Inc., 113 F.3d 1246 (10th Cir. 1997) (unpublished disposition) (citing Siefken to support the lower court's holding that an individual with bipolar disorder is not "qualified" if she needs accommodation because she failed to manage her disorder with medication).

I09. 163 F.3d 505 (8th Cir. I998).

110 . Id. at 506 .

111. Id. at 507.

112. Id.

113. See id. at 509 . 
It is legitimate for the City to expect and require that patrol officers keep themselves functional and alert at all times while on duty .... Burroughs failed to meet this legitimate expectation on two occasions, and the ADA does not require the City to provide him another chance to try to improve his diabetes monitoring technique while on duty as a patrol officer. ${ }^{114}$

Thus, despite the emphasis on causation in Burroughs, the court also seemed to conclude that the plaintiff could not perform the essential functions of his job.

The subtle emphasis on an employer's "legitimate job expectations" in Siefken and Burroughs is significant because it indicates that these cases should be construed narrowly. In both Siefken and Burroughs, the employer indicated that the plaintiff's successful control of his disability was a condition of employment. Further, in both cases, the employer's expectation that the employee would control his disability was linked to a belief that the employee's uncontrolled disabled state would pose a risk to the safety of others. As will be explained in Part III, these facts indicate that these cases should not be read broadly as imposing a mitigation requirement on disabled individuals seeking ADA protection. Rather, these cases demonstrate that in situations where an employee will pose a direct threat ${ }^{115}$ to others unless she controls her disability, the failure to control her disability renders the employee unqualified for her position and severs the requisite causal connection between disability and discrimination.

Subsequent courts have not, however, viewed the holdings of Siefken and Burroughs as narrowly limited to direct-threat situations. In Van Stan v. Fancy Colours \& Co., a jury rejected the plaintiff's ADA claim that he had been terminated from his job because of his bipolar disorder. ${ }^{116}$ The plaintiff appealed, arguing that the district court should not have allowed his treating physician to be cross-examined about whether marijuana use would have infiuenced the effectiveness of the plaintiff's bipolar disorder medication. ${ }^{177}$ The circuit court began its analysis of the issue by citing Siefken for the surprismgly broad proposition that "[a] plaintiff cannot recover under the ADA if through his own fault he fails to control an otherwise controllable illness." 118 Based on nothing more than this citation to Siefken, the court concluded that questions about "whether any factors within Van Stan's control... may have prevented the medication from controlling his disorder" were relevant, including questions about the impact of illicit drug use on the effectiveness of the plaintiff's

114. Id. at 507.

115. For an explanation of "direct threat," see supra Part I.C.

116. 125 F.3d 563, 566-67 (7th Cir. 1997).

117. Id. at 570 . The plaintiff argued that the defendant did not properly preserve the plaintiff's alleged drug use as an issue for trial. Id.

I18. Id. 
medication. ${ }^{119}$ In reaching this conclusion, the court did not attempt to reconcile the factual distinctions between Van Stan and Siefken. Unlike the situation in Siefken, however, the plaintiff in Van Stan did not pose a direct threat in his unmitigated state. ${ }^{120}$ Thus, Van Stan represents an expansive interpretation of Siefken because it considers a plaintiff's failure to control his disorder relevant even in the absence of a direct-threat situation. ${ }^{121}$

\section{Cases Implicating the Disability Definition}

One year after Siefken, a district court in the Third Circuit took a radically different approach to the issue of whether the ADA protects nonmitigating plaintiffs. Pangalos v. Prudential Insurance Co. of America considered whether an ADA plaintiff who had failed to control his physical disorder had a "disability" within the meaning of the statute. ${ }^{122}$ The plaintiff, an insurance salesman, was seeking certain accommodations from his employer due to a severe case of ulcerative colitis, a disease that leads to uncontrollable diarrhea, bloody stools, and painful hemorrhoids. ${ }^{123}$ The court ruled in favor of the defendant, holding that the plaintiff could not perform the essential functions of his job as an insurance salesman if he was subject to sudden onslaughts of diarrhea. ${ }^{124}$ ln addition, after noting that surgical removal of the colon was a "reliable and permanent cure" for ulcerative colitis but that the plaintiff had chosen not to undergo such surgery, ${ }^{125}$ the court stated that an alternate basis for its holding was that the plaintiff was not "disabled" because the disability he alleged "could readily be remedied surgically." 126

In Testerman v. Chrysler Corp., a 1997 district court case arising in the same circuit as Pangalos, the court reasoned that a person who fails to use available mitigating measures is not substantially limited ${ }^{127}$ in a major life activity, ${ }^{128}$ and therefore not disabled within the meaning of the

119. Id. Although the court was concerned about the prejudicial nature of a question about illicit drug use, the court ultimately determined that any error in allowing the question was harmless because a reasonable jury could have concluded that Van Stan's case failed on other elements. Id. at 570-72.

120. See id. at 566-67. The plaintiff's employer maintained that he was terminated due to his "'low productivity' and poor people management skills." Id. at 567.

121. One explanation for this broad interpretation is that the Van Stan court viewed Siefken as holding that the failure to comply with treatment regimens is a type of misconduct that severs the casual link between disability and discrimination. This misconduct-disability distinction is discussed in Part 111.B.1.c.

122. No. 96-0167, 1996 WL 612469 (E.D. Pa. Oct. 15, 1996).

123. Id. at *1.

124. Id. at *3.

125. Id. See infra Part Ill.B.1 for an explanation of why it is impermissible for courts to speculate that surgery will be a "reliable and permanent cure" for a particular ADA plaintiff.

126. Pangalos, $1996 \mathrm{WL} 612469$, at *3.

127. See supra text accompanying notes 46-48 for an explanation of "substantially limited."

128. See supra notes $42-44$ and accompanying text for a discussion of "major life activity." 
ADA. ${ }^{129}$ The Testerman plaintiff alleged several disabilities, including back sprain, depression, and diabetes. ${ }^{130}$ In evaluating the summary judgment motions of both parties, the court concluded that there was no evidence that the plaintiff "could have or should have" engaged in any activities that would have further mitigated his back sprain ${ }^{131}$ or his depression. ${ }^{132}$ With regard to the plaintiff's diabetes, however, the court found evidence that the plaintiff "did not consistently monitor his condition, take his insulin, or otherwise control his diabetes to the greatest degree possible."133 The court concluded that the defendant employer had "raised a genuine dispute as to whether [the plaintiff's] diabetes would have been substantially limiting if it had been more diligently treated." 134 The court's opinion seemed to suggest that if the plaintiff failed to use appropriate mitigating measures for his diabetes, the court would evaluate his diabetes in a hypothetical properly mitigated state rather than in its actual state. ${ }^{135}$ The court softened this rule, however, by noting that if the plaintiff's depression had affected his ability to comply with his diabetes regimen, then the plaintiff would not be "penalized" for his failure to mitigate and his diabetes would be evaluated in its actual state. ${ }^{136}$

In 1998 a district court in the Tenth Circuit considered a case involving mitigation of a psychiatric disorder. ${ }^{137}$ The plaintiff in Bowers $v$. Multimedia Cablevision, Inc. was diagnosed with major depression accompanied by anxiety and panic attacks. ${ }^{138}$ The plaintiff's physician prescribed a treatment of antidepressant medication. ${ }^{139}$ Contrary to the directions of his doctor, however, the plaintiff stopped taking his medication within one month. ${ }^{140}$ Although the court acknowledged that the plaintiff's mental condition substantially limited major life activities when it was untreated, the court emphasized that the plaintiff's condition was not substantially limiting when he took his medication as prescribed. The

129. No. CIV.A95-240, 1997 WL 820934, at *9-10 (D. De1. Dec. 30, 1997).

130. Id. at $* 7$.

131. Id. at $* 11 \mathrm{n} .22$.

132. Id. at $* 11$.

133. Id. at $* 12$.

134. Id. at *13.

135. See id. at ${ }^{*} 10, * 13$.

136. Id. at *13 (" $[1] \mathrm{f}$ Testerman establishes... that he suffered from depression or other mental condition.... and was thereby prevented from adhering to prescribed medical treatment for his diabetes, he may not be penalized for any related failure to mitigate the diabetes and his condition must be evaluated in the state presented."). See also id. at *10 ("[W]hen a qualifying impairment that can ordinarily be controlled is not controlled because, for example, a mental illness precludes the person from strictly adhering to a medical regimen, the ADA provides protection.").

137. See Bowers v. Multimedia Cablevision, Inc., No. CIV.A. 96-1298, 1998 WL 856074, at *4 (D. Kan. Nov. 3, 1998).

138. Id. at $* 1$.

139. Id.

140. Id. 
court noted that the plaintiff's one panic attack occurred after he had quit taking his medication, and then concluded that the plaintiff could not obtain ADA protection "by unilaterally deciding, without justification, not to use prescribed medication which corrects or alleviates his condition." ${ }^{\mid 41}$ Thus, even though the plaintiff had a "disability" within the meaning of the ADA when his mental condition was untreated, the court denied his ADA claim based on its conclusion that he would not have been disabled if he had taken his medication. Notably, the opinion did not contain any discussion of the plaintiff's reasons for not taking his medication.

In sum, the cases prior to Sutton employed a variety of rationales to deny ADA coverage to individuals who did not use mitigating measures. Taken together, the cases suggested that the nonuse of available mitigating measures can affect a court's determination of disability, qualification, and causation. In other words, every element of a plaintiff's case may fail due to a plaintiff's nonuse of available mitigating measures.

Further, the courts seemed eager to apply the "failure to control a controllable disability" doctrine expansively. Although the holdmgs of Siefken and Burroughs could be viewed narrowly as limited to situations in which the plaintiffs' successful control of their disabilities was a condition of employment due to safety concerns, the Van Stan court cited Siefken for the broad proposition that a plaintiff loses ADA coverage if through her own fault she fails to control an otherwise controllable disability. Similarly, despite the fact that the Testerman court recognized the complex factors potentially at work in situations in which a mentally ill individual fails to take his psychotropic medication, the Bowers court denied ADA coverage to such an individual without any discussion of whether the plaintiff's mental illness had played a role in his failure to comply with the medication regimen.

Finally, the courts in these pre-Sutton cases tended to engage in speculation regarding the question of whether an individual would be substantially limited in a hypothetical state of mitigation. Indeed, for a court to deny recovery based on a plaintiff's nonuse of available mitigating measures, the court must necessarily first conclude that the disability is of a type that can usually be mitigated, and in addition, that the disability can be successfully mitigated in the plaintiff's specific case. As the next section will demonstrate, the ADA prohibits such speculation.

\section{B. Analysis of Sutton and Its Implications for Lower Courts}

The Supreme Court addressed the role of mitigating measures in the definition of disability in a trio of ADA cases decided in 1999: Sutton $v$. United Air Lines, Inc., ${ }^{142}$ Murphy v. United Parcel Service, Inc. ${ }^{143}$ and

141. Id. at *4.

142. 527 U.S. 471 (1999). 
Albertson's, Inc. v. Kirkingburg. ${ }^{144}$ In Sutton, the lead case of the trio, the Court held that "if a person is taking measures to correct for, or mitigate, a physical or mental impairment, the effects of those measures-both positive and negative-must be taken into account when judging whether that person is 'substantially limited' in a major life activity and thus 'disabled' under the Act."145 Sutton answered the question of whether twin sisters who suffered from severe visual myopia had a "disability" within the meaning of the ADA even though their vision was $20 / 20$ or better when they wore corrective lenses. ${ }^{146}$ The Court concluded that the plaintiffs were not disabled under the Act because they were not substantially limited in any major life activity when they used corrective lenses. ${ }^{147}$

In reaching this conclusion, the Court espoused a broad view of the types of mitigating measures that should be taken into account in determining whether an individual is "disabled" within the meaning of the ADA. According to the Court, the effects of such medical devices as contact lenses, eyeglasses, hearing aids, and prosthetic limbs should be considered, as well as medication. ${ }^{148}$ Additionally, Kirkingburg made clear that mitigation by the human body's own systems must be taken into account. ${ }^{149}$ Specifically, the Court held that the plaintiff's ability to subconsciously compensate for his monocular vision was a mitigatimg measure..$^{150}$

The Sutton Court provided three reasons for its conclusion that courts must take the plaintiff's current use of mitigating measures into account when making a disability determination under the ADA. First, the Court emphasized that the ADA definition of disability as "a physical or mental impairment that substantially limits one or more... major life activities" appears in the present indicative verb form. ${ }^{151}$ According to the Court,

the language is properly read as requiring that a person be presently - not potentially or hypothetically-substantially limited

143. 527 U.S. 516,521 (1999) (holding that the plaintiff's use of medication to mitigate his high blood pressure must be taken into account in the court's determination of whether his impairment substantially limited a major life activity). Murphy is significant because it indicated that the Court's holding in Sutton extended to mitigating measures like medication. Meadows \& Bales, supra note 15, at 47.

144. 527 U.S. 555, 565-66 (1999) (holding that the subconscious mechanism that the plaintiff used to compensate for his monocular vision was a mitigating measure that must be taken into account when determining whether the plaintiff was disabled within the meaning of the ADA). Kirkingburg is significant because it clarified that when courts consider the effect of mitigating measures on the question of whether an ADA plaintiff has a "disability," they must consider not only external mitigating measures, such as corrective medical devices and medication, but also mitigating measures taken by the body's own systems (consciously or not). Meadows \& Bales, supra note 15, at 48.

145. Sutton, 527 U.S. at 482.

146. Id. at 475 .

147. Id. at 488 .

148. II. at $475,485,488$.

149. Kirkingburg, 527 U.S. at 565-66.

150. Id.

151. Sutton, 527 U.S. at 482 (citing 42 U.S.C. $\$ 12102$ (2)(A) (emphasis omitted)). 
to demonstrate a disability. A "disability" exists only where an impairment "substantially limits" a major life activity, not where it "might," "could," or "would" be substantially limiting if mitigating measures were not taken. ${ }^{152}$

Second, the Court emphasized that the ADA mandates an individualized inquiry into the question of whether an individual is disabled. ${ }^{153}$ The Court cited statutory language stating that the existence of a disability must be evaluated "with respect to an individual" and must be determined based on whether an impairment substantially limits the "major life activities of such individual." 154 To make a disability determination without reference to mitigating measures, a court would be forced to evaluate individuals who currently mitigate their impairments in a hypothetical unmitigated state. According to the Court, such speculation about an individual's functioning in an unmitigated state would require courts and employers "to make a disability determination based on general information about how an uncorrected impairment usually affects individuals, rather than on the individual's actual condition." 155 The Court went on to say that such an analysis "would create a system in which persons often must be treated as members of a group of people with similar impairments, rather than as individuals. This is contrary to both the letter and the spirit of the ADA."156

Third, the Court asserted that a definition of disability that encompassed individuals who were not disabled in their mitigated state would extend coverage to a much larger group of people than Congress intended. ${ }^{157}$ To support this assertion, the Court cited a congressional finding that " $43,000,000$ Americans have one or more physical or mental disabilities." 158 The Court then compared this figure to the much larger number of Americans who would qualify as disabled if the statute encompassed individuals whose disabilities are remedied with corrective measures, such as the 100 million visually-impaired individuals who function normally with corrective lenses. ${ }^{159}$

As acknowledged by several courts and commentators, nothing in Sutton suggests that ADA plaintiffs must use available mitigating measures to obtain ADA coverage; nor does Sutton suggest that ADA plaintiffs who do not currently mitigate their impairments must be evaluated for ADA coverage based on a hypothetical mitigated state. ${ }^{160}$ Rather, as the language

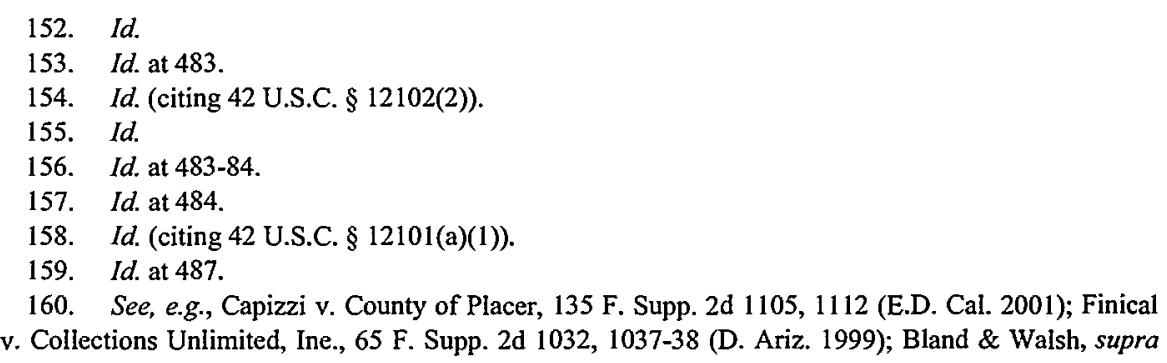


of the Court's holding demonstrates, the mitigating measures analysis required by Sutton is triggered only "if" a disabled individual presently employs such measures. ${ }^{161}$ Presumably, the Court was aware of the pre-Sutton cases in multiple circuits which emphasized that the failure to control a controllable disability renders a plaintiff ineligible for $\mathrm{ADA}$ protection. Thus, the narrow language of the Sutton Court's holding suggests that the Court purposefully declined to require that ADA plaintiffs mitigate their disabilities to receive ADA protection. Indeed, the same reasoning that supported the Court's conclusion that initigating measures must be considered when an individual is currently using such measures demands the opposite conclusion with regard to an individual who is not presently using mitigating measures. ${ }^{162}$ As einphasized by the Court, the plain language of the statute indicates that an imdividual's impairment should be evaluated in its present state rather than in a hypothetical state where it "might, could, or would" be substantially limiting. ${ }^{163}$ Siguificantly, the Court explicitly applied this reasoning to the situation in which an individual does not use mitigating measures: "The use or nonuse of a corrective device does not determine whether an individual is disabled; that determination depends on whether the limitations an individual with an impairment actually faces are in fact substantially limiting."164

This view of Sutton's import for "failure to control a controllable disability" cases was directly acknowledged in Finical v. Collections Unlimited, Inc., a 1999 district court case arising in the Ninth Circuit. ${ }^{165}$ In Finical the plaintiff, who worked as a telephone collector for a collections company, asked her employer to accommodate her hearing impairment with a headset that would amplify telephone conversations. ${ }^{166}$ When she was subsequently terminated, she sued for disability discrimination. ${ }^{167}$ The defendant argued that the plaintiff would not have been substantially limited in the major life activity of hearing if she had used a hearing aid. ${ }^{168}$ The plaintiff asserted that she had tried a hearing aid for one month but that she had stopped using it because it registered background noise that annoyed her. ${ }^{169}$ The defendant, on the other hand, cited testimony by one of the plaintiff's expert medical witnesses stating that the plaintiff would

note 88, at 26; Burke \& Abel, supra note 16, at 807; Eichhorn, supra note 2, at 1110; Meadows \& Bales, supra note 15 , at 54 .

161. Sutton, 527 U.S. at 482.

162. See Finical, 65 F. Supp. 2d at 1037; Eichhorn, supra note 2, at 1111; Meadows \& Bales, supra note 15, at 54 .

163. Sutton, 527 U.S. at 482 (internal quotations omitted).

164. Id. at 488 (emphasis in original).

165. 65 F. Supp. 2d 1032 (D. Ariz. 1999).

166. Id. at 1035,1038 .

167. Id. at 1035 .

168. Id. at 1037.

169. Id. 
benefit from a hearing aid. ${ }^{170}$ In light of Sutton, however, the court was not persuaded by the speculative testimony cited by the defendant:

[T]he Supreme Court requires a case-by-case analysis of the limitations an individual faces in his or her current state .... [A]n individualized inquiry into the limitations faced by a claimant who uses corrective devices is inconsistent with an evaluation focusing on the limitations the claimant would face in an uncorrected state. Likewise, an individualized inquiry into the limitations faced by a claimant who does not use corrective devices is inconsistent with an evaluation focusing on the limitations the claimant would face in a corrected state. Both approaches frequently require speculation-with respect to the latter, speculation about the limitations a plaintiff would face if she used a corrective measure she presently does not use, and, with respect to the former, speculation about the limitations a plaintiff would face if she stopped using a corrective measure she presently uses. Neither approach assesses the limitations the individual actually faces in the present. ${ }^{171}$

Thus, the court refused to engage in a speculative analysis of whether the plaintiff's disability would have been substantially limiting if she had used a hearing aid.

Indeed, as the following passages will illustrate with examples and empirical evidence, for a court to conclude that a nonmitigating plaintiff would not be disabled in a hypothetical mitigated state, the court inust speculate that the treatment would be effective for the particular plaintiff, that the side effects of the treatment would not substantially limit the particular plaintiff, and that the symptoms of the plaintiff's disability would not prevent her from complying with treatment. As established above, all of these types of speculation are prohibited by Sutton.

\section{Speculation Regarding the Effectiveness of Treatment}

To conclude that a plaintiff's disability would be controlled with mitigating measures, courts must evaluate individuals in a hypothetical mitigated state. For instance, imagine a case in which the mitigating measure involves a surgery that is almost always effective and that poses an extremely low risk of complications. To deny ADA coverage to a plaintiff who chooses not to undergo such surgery, a court must speculate that the procedure will be successful for a particular disabled individual because it is successful for most people. Such a line of reasoning involves exactly the type of speculation that the Sutton Court condemned as incompatible with an individualized inquiry. ${ }^{172}$ Despite the probabilities, there is still a slight

170. Id.

171. Id. at 1038 (internal citations omitted).

172. Sutton v. United Air Lines, Inc., 527 U.S. 471, 483-84 (1999). 
chance that surgery will actually be dangerous or ineffective for the particular plaintiff.

The type of speculation proscribed by Sutton is further illustrated by some of the nonmitigation cases discussed in Part II.A. For instance, in Siefken, the court supported its view that the plaintiff's diabetes would be controlled with mitigating measures merely by citing an American Diabetes Association brief stating that "with current technology and proper monitoring, most diabetics can reduce the chances of a severe hypoglycemic reaction to virtually nil."173 Thus, the Siefken court's analysis did not consider whether the disability was controllable in the plaintiff's individual case. Nor did it consider the fact that even if proper monitoring reduces the risk of severe diabetic episodes, empirical evidence indicates that patient compliance with diabetes regimens is generally poor, ${ }^{174}$ suggesting that perhaps "proper monitoring" is the exception rather than the rule. In sum, Siefken exemplifies the Sutton Court's concern that courts will stray from the mandated individualized inquiry and instead evaluate ADA plaintiffs based on information about the general characteristics of people with the same disability. ${ }^{175}$

Similarly, Franklin ${ }^{176}$ concerned a plaintiff who suffered from paranoid schizophrenia. The court stated that her condition was "reasonably controllable by the use of medication"177 and cited a clinical psychologist's report stating that "as long as [the plaintiff] takes her psychotropic medication she functions effectively in society." 178 However, empirical evidence indicates that a patient's past response to antipsychotic medications will not predict future responses accurately in every case. ${ }^{179}$ In addition, even when schizophrenic patients comply with their medication regimens, they may still experience additional psychotic episodes. ${ }^{180}$ For instance, one study of conventional antipsychotic medications found that a substantial percentage of schizophrenic patients relapse during the first

173. Siefken v. Village of Arlington Heights, 65 F.3d 664, 666 (7th Cir. 1995). For a detailed discussion of Siefken, see supra text accompanying notes 102-07.

174. Russell E. Glasgow, Compliance to Diabetes Regimens: Conceptualization, Complexity, and Determinants, in Patient Compliance in Medical Practice and Clinical Trials 209 (Joyce A. Cramer \& Bert Spilker eds., 1991).

175. See Sutton, 527 U.S. at 483.

176. Franklin v. U.S. Postal Serv., 687 F. Supp. 1214 (S.D. Ohio 1988); see supra text accompanying notes $92-101$.

177. Id. at 1216.

178. Id. at 1217.

179. See American Psychiatric Association, Schizophrenia: Treatment Principles and ALTERNATIVES, (2000) (describing a patient's past response to antipsychotic medications as a "fairly reliable predictor" of how the patient will respond to medication in the future), at http://www.medem.com/MedLB/articleslb.cfm?sub_cat=43 (last visited May 20, 2002) (on file with author) [hereinafter Schizophrenia: TREaTNIENT].

180. National Institute of Mental Health, Schizophrenia, at http://www.nimh.nih.gov/ publicat/schizoph.htm (last visited May 20, 2002) (on file with author) [hereinafter ScHIzOPHRENIA]. 
year of medication. ${ }^{181}$ Further, while antipsychotic drugs may be very effective in treating symptoms such as hallucinations and delusions, they may not be as helpful with other symptoms, such as reduced emotional expressiveness or motivation. ${ }^{182}$ Thus, although the details of the plaintiff's medical situation in Franklin are unclear (such as how long she had taken medication previously and what type of medication was prescribed), these medical facts demonstrate the speculative nature of the Franklin court's conclusion that her disorder was controllable.

\section{Speculation Regarding the Side Effects of Treatment}

Because Sutton requires analysis of both the positive and negative effects of corrective measures, ${ }^{183}$ a court that concludes that a plaintiff would not have been disabled if she had used mitigating measures is speculating that such measures would not produce negative side effects that substantially limit a major life activity. Sutton prohibits such speculation, however, because courts cannot know whether an ADA plaintiff's use of a mitigating measure would have led to negative side effects that were substantially limiting in the plaintiff's particular case. For instance, individuals being treated for schizophrenia with conventional antipsychotic medications ${ }^{184}$ frequently report side effects of dizziness, blurred vision, restlessness, and sexual dysfunction. ${ }^{185}$ In addition, people taking these antipsychotics often develop dysfunctions in the nerve tracts that resemble the symptoms of Parkinson's disease, including tremors of the fingers, a shuffling gait, drooling, and muscular rigidity. ${ }^{186}$ Further, 10 to $20 \%$ of patients treated with antipsychotics for a long period of time develop a muscular disturbance called tardive dyskinesia, characterized by involuntary movements of the mouth, lips, and tongue. ${ }^{187}$ Tardive dyskinesia is not responsive to any known treatment. ${ }^{188}$ Finally, neuroleptic malignant syndrome occurs in about $1 \%$ of cases and can sometimes be fatal; it is characterized by severe muscular rigidity and fever. ${ }^{189}$

181. See SCHIZOPHRENIA: TREATMENT, supra note 179 (noting that $24 \%$ of schizophrenic patients relapsed during the first year despite compliance with their prescribed medication regimens).

182. Schizophrenia, supra note 180. See also Gerald C. Davison \& John M. Neale, ABNORMAL PSYCHOLOGY 305 (8th ed. 2001).

183. Sutton v. United Air Lines, 1nc., 527 U.S. 471, 483 (1999).

184. These medications were developed in the 1950 s and are sometimes referred to as "neuroleptics" because they produce side effects similar to the symptoms of a neurological disease. DAVison \& NeAlE, supra note 182, at 305.

185. Id.; see also SCHIZOPHRENIA supra note 180 .

186. DAvison \& NEALE, supra note 182 , at 305.

187. Id.; see also SCHIZOPHRENIA, supra note 180. Tardive dyskinesia can also develop in patients who have been treated with these drugs for a shorter period of time. Id. Further, antipsychotic drugs developed in recent years may also produce tardive dyskinesia. Id.

188. Davison \& Neale, supra note 182, at 305; National SCh1zophrenia, supra note 180.

189. DAVISON \& NEALE, supra note 182 , at 305. 
Although a relatively new drug called clozapine has produced greater therapeutic gains and fewer motor side effects than traditional antipsychotics, it can impair the immune system of a small number of schizophrenic patients (about 1\%) by lowering the number of white blood cells, thereby leading to infection and even death. ${ }^{190}$ Patients who take clozapine must be monitored for this condition with blood tests every two weeks. ${ }^{191}$ Clozapine can also produce seizures, dizziness, fatigue, drooling, and weight gain. ${ }^{192}$

As the above discussion illustrates, despite the range of available antipsychotic drugs, both newer and older drugs may result in substantial negative side effects that could substantially limit a major life activity. Indeed, the severity of these side effects is illustrated by the fact that about one half of the patients who take antipsychotic drugs discontinue their use after one year due to side effects. ${ }^{193}$

The problem of severe negative side effects is not limited to rare disorders such as schizophrenia. For instance, users of tricyclic antidepressants (such as Tofranil and Elavil) risk heart attack, stroke, hypotension, blurred vision, anxiety, tiredness, dry mouth, constipation, gastric disorders, erectile failure, and weight gain. ${ }^{194}$ These side effects lead as many as 30 to $40 \%$ of patients to stop taking their medication because they think that "the cure is worse than the disease." 195 Nor are adverse side effects limited to treatments for mental disorders. For instance, the eyedrops used to treat glaucoma, the third leading cause of blindness in the United States, can produce localized side effects (stimging, burning, reduced vision) as well as potentially more serious systemic problems (depression, asthma, tachycardia, and congestive heart failure). ${ }^{196}$

This medical information about the side effects associated with schizophrenia, depression, and glaucoma illustrates that courts often cannot reliably predict whether a mitigating measure will lead to severe side effects that substantially limit a particular individual.

190. Id. at 307; SCHIZOPHRENIA, supra note 180.

191. SCHIZOPHRENIA, supra note 180.

192. DAVISON \& NEALE, supra note 182 , at 307.

193. Id. at 305.

194. Id. at 265.

195. David H. Barlow \& V. Mark Durand, Abnormal Psychology 280 (1995). The two other main types of antidepressant medications also produce serious side effects. Monoamine oxidase (MAO) inhibitors (such as Parnate) can result im possibly fatal hypertension, dry mouth, dizziness, nausea, and headaches. DAvISON \& NEALE, supra note 182 , at 265 . Selective serotonin reuptake inhibitors (such as Prozac) can result in nervousness, fatigue, gastrointenstinal complaints, dizziness, headaches, and insomnia. Id.

196. Mae E. Gordon \& Michael A. Kass, Validity of Standard Compliance Measures in Glaucoma Compared with an Electronic Eyedrop Monitor, in Patient Compliance In Medical PRACtice AND Clinical Trials 163 (Joyce A. Cramer \& Bert Spilker eds., 1991). 


\section{Speculation Regarding the Plaintiff's Ability to Comply with Treatment}

In cases where noncompliance with treatment regimens can stem from the symptoms of the plaintiff's disability itself, a court that concludes a disability is "controllable" is speculating that the plaintiff is capable of complying with treatment. For instance, patients with schizophrenia may not believe they are ill or they may have such disorganized thinking that they forget to take prescribed medication. ${ }^{197}$ The former tendency was demonstrated by the schizophrenic plaintiff in Franklin, who stated that she did not go to the clinic to get more medication because she did not think there was anything wrong. ${ }^{198}$ Similarly, denial of illness is a prominent aspect of bipolar disorder and may sometimes interfere with the patient's ability to make reasonable treatment decisions. ${ }^{199}$ Ironically, in such cases the failure to comply with prescribed treatment may actually be evidence of disability as opposed to a factor that precludes a finding of disability. This important link between the symptoms of a disability and the failure to comply with treatment programs was emphasized by the Testerman court, which stated that "when a qualifying impairment that can ordinarily be controlled is not controlled because, for example, a mental illness precludes the person from strictly adhering to a medical regimen, the ADA provides protection." 200

Empirical research suggests that complying with medical treatment regimens is difficult even when an individual does not suffer from a mental disorder that affects her perception of illness. Partial noncompliance with treatment is commonly reported for patients with a wide range of medical disorders, including heart failure, epilepsy, and glaucoma. ${ }^{201}$ One expert has linked noncompliance with a lack of acute symptoms of illness. She reports that medical patients tend to deny the need for treatment of asymptomatic conditions, such as hypertension and elevated lipid levels, and that many patients discontinue treatment for symptomatic disorders, such as

197. SCHIZOPHRENIA, supra note 180.

198. Franklin v. U.S. Postal Serv., 687 F. Supp. 1214, 1216 (S.D. Ohio 1988). See also Davison \& NEALE, supra note 182, at 304 (noting that "many patients with schizophrenia lack insight into their impaired condition and refuse any treatment at all").

199. American Psychiatric Association, Bipolar Disorder: Treatment Principles (1994), at http://www.medem.com/MedLB/articleslb.cfm?sub_cat=46 (last visited May 20, 2002) (on file with author). In addition, bipolar individuals who experienee manic episodes often stop taking their medication to regain the pleasurable euphoric feelings that accompany a manic episode. BARLOw \& DiJRAND, supra note 195, at 282.

200. Testerman v. Chrysler Corp., No. CIV.A.95-240, 1997 WL 820934, at*10 (D. Del. Dec. 30, 1997). For a discussion of Testerman, see supra text accompanying notes 127-36.

201. Joyce A. Cramer \& Richard H. Mattson, Monitoring Compliance with Antiepileptic Drug Therapy, in Patient Compliance in Medical Practice and Clinical Trials 129 (Joyce A. Cramer \& Bert Spilker eds., 1991). 
infections, as soon as the acute symptoms are alleviated. ${ }^{202}$ According to another expert, patient compliance with diabetes regimens is generally poor, ${ }^{203}$ although patients tend to be more compliant with the medical aspects of the diabetes regimen (such as medication and insulin injections) than the lifestyle aspects of the regimen (such as diet and exercise) ${ }^{204}$ This empirical evidence of widespread patient noncompliance with treatment regimens suggests that it is often difficult for patients to comply with prescribed treatment, and that therefore it may be unrealistic for a court to assume that a particular plaintiff is capable of compliance. Thus, even in cases involving only medical disorders, a court's conclusion that the patient is capable of complying with treatment entails prohibited speculation.

\section{After Sutton: The Ongoing Denial of ADA Coverage to Nonmitigating Plaintiffs}

The preceding discussion has established that speculation about an ADA plaintiff's functioning in a hypothetical mitigated state is prohibited by the statute. Although this prohibition arguably extends to any speculation that would undermine the individualized inquiry mandated by the statute, Sutton itself concerned only the disability determination. Thus, at a minimuin, speculation about a plaintiff's functioning in a hypothetical mitigated state is proscribed in the context of the disability determination. However, several courts since Sutton have iguored the prohibition on speculation in the disability determination. Outside the context of the disability determination, one court has ignored Sutton altogether by mechaincally reciting the "Siefken rule." Further, some commentators who acknowledge Sutton's prohibition on speculation have used the prohibition as a new justification for denying ADA coverage.

\section{The Continued Role of Speculation in the "Disability" Determination}

Although Finical recognized that Sutton prohibits speculation about an ADA plaintiff's functioning in a hypothetical mitigated state, not all courts have responded to Sutton in this way. For instance, in Tangires $v$. Johns Hopkins Hospital, a district court in the Fourth Circuit granted summary judgment to the defendant due to the plaintiff's failure to take medication to alleviate her asthma. ${ }^{205}$ The Tangires court's reasoning was fiawed, however, because it reached conclusions that were inconsistent with the legal premises that it recited in its opinion. For example, the court

202. Joyce A. Cramer, Overview of Methods to Measure and Enhance Patient Compliance, in Patient Complance in Medical Practice and Clinical Trials 3 (Joyce A. Cramer \& Bert Spilker eds., 1991).

203. Glasgow, supra note 174 , at 210.

204. Id. at 211 .

205. 79 F. Supp. $2 d$ 587, 596 (D. Md. 2000). 
began by recognizing the importance of an individualized inquiry in ADA cases:

$[\mathrm{T}]$ he determination of whether a particular impairment constitutes a disability must be made on a case-by-case basis. The requirement in an ADA case that an individualized analysis should be made is particularly appropriate in the context of a disability claim based on asthma. The severity of asthma varies a great deal from person to person, and the frequency with which a person experiences asthmatic episodes also varies greatly. ${ }^{206}$

Immediately after acknowledging the importance of an individualized inquiry and the individual differences between asthmatics, however, the court stated that "[w]ith proper treatment, asthmatic symptoms can almost always be controlled."207

Another example of inconsistency in the Tangires opinion is the court's citation of Sutton and Murphy for the proposition that "the determination of a plaintiff's disability must be made with reference to the mitigating measures which the plaintiff employs." ${ }^{208}$ Although the court's use of the present tense ("employs") suggests that it recognized that the Sutton holding was limited to mitigating measures currently used by the plaintiff, the court proceeded to analyze the plaintiff's claim as if there was no distinction between mitigating measures presently used by a plaintiff and those not used by a plaintiff.

The court's analysis of the plaintiff's claim began with its citation to medical evidence that asthma can be completely controlled by medication. ${ }^{209}$ Next, it noted that the plaintiff had refused to take medications or to follow her doctors' treatment instructions. ${ }^{210}$ The court also attributed the plaintiff's inability to control her asthma to the fact that she "persistently fragmented her medical care by seeking treatment from so many different doctors and in various emergency rooms of different hospitals."211 The court disregarded evidence that the plaintiff refused to treat her asthma with inhaled steroids because she believed that such medications would adversely affect another medical condition (pituitary adenoma). ${ }^{212}$ Although one of the plaintiff's doctors reported that the plaintiff "almost went into a panic and developed very childish behavior" at the idea of taking such medication, the court did not acknowledge the subjective nature of fears about medical treatment. Instead, the court merely described the

206. Id. at 594-95 (internal citations omitted). Notably, the court does not cite Sutton for the proposition that the disability determination must be made on a case-by-case basis. See id.

207. Id. at 595 .

208. Id.

209. Id. at 595-96.

210. Id. at 596 .

211. Id. at 595 .

212. Id. at 596 . 
plaintiff's fears as "unsubstantiated" and inconsistent with the beliefs of the plaintiff's doctors. ${ }^{213}$ The court also noted that after the plaintiff's employment with the defendant was terminated, she did take steroid medication and her asthma subsequently improved. ${ }^{214}$ Based on this evidence, the court concluded that

[P]laintiff's asthma was treatable and... during her employnent she intentionally failed to follow her physicians' recommendations that she take steroid medication. Since plaintiff's asthma is correctable by medication and since she voluntarily refused the recommended medication, her asthma did not substantially limit her in any major life activity. ${ }^{215}$

Thus, Tangires ignored the reasoning of Sutton and speculated that the plaintiff would not have been substantially limited if she had followed the instructions of her doctors. Remarkably, the court was so confident in its speculation that the plaintiff's case did not even survive summary judgment. The final words of the court's holding also declared, without any explanation other than a citation to a pre-Sutton district court decision from 1996, that "a plaintiff who does not avail herself of proper treatment is not a 'qualified individual' under the ADA."216

Despite its legal weaknesses, the Tangires approach to nonmitigating plaintiffs has been favorably cited in subsequent district court opinions im the Second and Fourth Circuits. Like the Tangires court, these courts explicitly acknowledged the Sutton holding in their opinions ${ }^{217}$ and yet ignored its implications. A district court in the Fourth Circuit discussed Tangires in its analysis of whether the defendant's motion to dismiss should be granted on the grounds that the plaintiff did not have a "disability." 218 In connection with its acknowledgment of Tangires, the court noted that it was assuming for purposes of the defendant's motion that the plaintiff was taking all appropriate medication. ${ }^{219}$ Similarly, another district court in the Fourth Circuit invoked Tangires in discussing whether the plaintiff did not have a "disability" because the plaintiff did not use his steroid nasal sprays as instructed by his doctors. ${ }^{220}$ The court concluded that it was unclear from the record whether the plaintiff had properly used his nasal sprays, and therefore it assumed for the purposes of summary judgment motion that the plaintiff had properly used the

213. Id.

214. Id.

215. Id.

216. Id. (citing Roberts v. County of Fairfax, 937 F. Supp. 541,549 (E.D. Va. 1996)).

217. Rose v. Home Depot U.S.A., Inc., 186 F. Supp. 2d 595, 611 (D. Md. 2002); Hewitt v. Alcan Aluminum Corp., 185 F. Supp. 2d 183, 188-89 (N.D.N.Y. 2001); Saunders v. Baltimore County, 163 F. Supp. 2d 564, 568 (D. Md. 2001).

218. Saunders, 163 F. Supp. $2 \mathrm{~d}$ at $566,568-69$.

219. Id.

220. Rose, 186 F. Supp. 2d at 612-14. 
sprays. ${ }^{221}$ Lastly, a district court in the Second Circuit stated in dicta that the plaintiff was not protected by the ADA if his failure to take his medication for his posttraumatic stress disorder ("PTSD") had played a causative role in the accidents that led to the termination of his employment. ${ }^{222} \mathrm{Ac}$ cording to the court, "since plaintiff admits that his PTSD is correctable by medication which he voluntarily chose not to take, his PTSD did not substantially limit him in any major life activity." ${ }^{3223}$ The court supported this conclusion by citing Tangires for the proposition that "[a] plaintiff who does not avail himself of corrective medication is not a qualified individual under the ADA."224 Thus, it appears that these district courts accepted the Tangires view of an ADA plaintiff's nonuse of mitigating measures, even though any further discussion of such nonuse inevitably would require a court to engage in prohibited speculation about whether such measures would have been effective for the particular plaintiff.

\section{Reliance on a Broad Interpretation of Siefken}

While Tangires improperly interpreted the Sutton holding to extend to cases where a plaintiff does not presently use mitigating measures, Brookins v. Indianapolis Power \& Light Co. ${ }^{225}$ ignored the existence of Sutton altogether. Although the early pages of the Brookins opinion established that the plaintiff was neither qualified nor disabled within the ineaning of the $A D A,{ }^{226}$ the court went on to evaluate the plaintiff's case in a separate subsection entitled "Siefken Rule."227 The court began by citing Van Stan's broad interpretation of the Siefken holding: "A plaintiff cannot recover under the ADA if through his own fault he fails to control an otherwise controllable illness." ${ }^{228}$ The court also cited the language of the Siefken holding itself: "We ... hold that when an employee knows that he is afflicted with a disability, needs no accommodation from his employer, and fails to meet the employer's legitimate job expectations, due to his failure to control a controllable disability, he cannot state a cause of action under the ADA."229 The court then applied the literal language of the Siefken holding to the plaintiff's case. According to the court, because the plaintiff knew he was afflicted with the disabilities of depression and anxiety, requested no accommodation from his employer, did not meet his employer's legitimate job expectation of regular attendance, and admitted that

221. Id. at 613-14.

222. Hewitt, 185 F. Supp. 2d at 189 (ultimately granting the defendant's summary judgment motion on the ground that the plaintiff posed a threat to the safety of himself and other employees).

223. Id.

224. Id.

225. 90 F. Supp. $2 d 993$ (S.D. Ind. 2000).

226. Id. at 1001-02.

227. Id. at 1006.

228. Id. (quoting Van Stan v. Fancy Colours \& Co., 125 F.3d 563, 570 (7th Cir. 1997)).

229. Id. (quoting Siefken v. Village of Arlington Heights, 65 F.3d 664, 667 (7th Cir. 1995)). 
his conditions would be controllable by medication but failed to obtain such medication, he could not state a cause of action under the ADA..$^{230}$

In sum, the Brookins court, like the Van Stan court, ${ }^{231}$ interpreted Siefken broadly by suggesting that the failure to control a disability precludes ADA coverage even when such failure does not pose a threat to the safety of others. However, as this Comment will show, ${ }^{232}$ courts need not resort to a mechanical recitation of the Siefken holding to achieve what they perceive to be a just result. Rather, the Brookins and Van Stan courts could have reached the same results by employing the existing constructs expressly provided by Congress in the ADA. Indeed, in Brookins, the entire discussion of the Siefken rule was superfluous, as the court had already determined that the plaintiff was ineligible for $\mathrm{ADA}$ protection because he was neither disabled nor qualified.

\section{The Prohibition on Speculation as a New Justification for Denying ADA Protection}

Some commentators have used Sutton as a new justification for denying ADA coverage based on an individual's allegedly inadequate use of available mitigating measures. Dr. Perry Meadows and Professor Richard Bales have suggested that when an ADA plaintiff refuses to follow a treatment regimen prescribed by her physician,

the individual should be evaluated according to the state of her impairment while she is following the treatment plan. If she has never complied with the treatment plan, and it is therefore impossible to determine conclusively what her state would be under the plan, she should not be protected under the ADA. ${ }^{233}$

Thus, Meadows and Bales suggested that a court can sidestep the Sutton prohibition on speculation by denying ADA coverage to a plaintiff whose functioning in a mitigated state cannot be evaluated without speculation. As support for this viewpoint, Meadows and Bales referred to Sutton, stating that "some guidance may be inferred from the Court's prescription that the phrase 'substantially limits' should be interpreted as directing courts to look to an individual's actual present limitations, and not potential or hypothetical limitations." ${ }^{234}$ Meadows and Bales also contended that their approach was "consistent with the body of case law that has developed

230. Id.

231. See supra text accompanying notes 116-21.

232. See infra Part III.B.

233. Meadows \& Bales, supra note 15, at 54. Meadows and Bales advocate a different rule where the patient is following a treatment regimen prescribed by a physician, even if the prescribed treatment regimen arguably is not the most effective. In such a circumstance, they assert that the plaintiff's disability should be evaluated in its present state. They cite to the Sutton trilogy's requirement that individuals be evaluated on a case-by-case basis in the present state of their condition. Id.

234. Id. 
around determinations of mental disability where the plaintiff has refused to take her medication. Under these circumstances, courts routinely refuse to extend ADA protection." 235 Significantly, the only legal authority that Meadows and Bales cited for this proposition was Bowers v. Multimedia Cablevision, Inc. ${ }^{236}$ a pre-Sutton case. ${ }^{237}$

In conclusion, the natural implication of Sutton's prohibition on speculation is that a nonmitigating plaintiff's disability should be evaluated in its unmitigated state. Nevertheless, Sutton has not prevented courts and commentators from continuing to insert a mitigation requirement into the ADA. Perhaps this is due in part to the narrowness of the Sutton holding, which did not directly concern nonmitigating plaintiffs and which pertained to only the "disability" element of a plaintiff"s case. Thus, a court arguably can still evaluate the disability of a nonmitigating plaintiff in a hypothetical mitigated state without defying Supreme Court precedent. Further, a court denying ADA protection to a nonmitigating plaintiff can also sidestep Sutton by grounding its holding in the qualification or causation elements of an ADA case. Alternatively, a court that recognizes the import of Sutton's prohibition on speculation can use that prohibition as a new justification for denying ADA coverage to nonmitigating plaintiffs whose functioning in an allegedly proper mitigated state cannot be evaluated without speculation. Given these loopholes in Sutton, Part III examines the statute's language, history, and structure to establish that Congress did not intend to deny $\mathrm{ADA}$ protection to nonmitigating plaintiffs.

\section{III}

\section{Analysis of the Statute's Language, History, ANd Structure}

This Part will demonstrate that Congress did not intend to permit courts to deny ADA coverage based on a plaintiff's nonuse of available mitigating measures. Part III.A goes beyond the speculation issue emphasized in Sutton and explains how the statute's language and history make it clear that plaintiffs who do not use available mitigating measures may still have a "disability" within the meaning of the statute. Part III.B illustrates that there is no need to manufacture a "failure to control a controllable disability" doctrine because the ADA already equips courts with the tools they need to protect the interests of employers as well as the interests of employees who decide to use mitigating measures.

236. See supra text accompanying notes 137-41.

237. Meadows \& Bales, supra note 15, at 54 (citing No. CIV.A.96-1298, 1998 WL 856074 (D. Kan. Nov. 3, 1998)). 


\section{A. Congressional Intent}

There are two possible ways in which a court could avoid the speculation prohibited by Sutton: by evaluating the plaintiff's disability in its current unmitigated state or by denying $\mathrm{ADA}$ coverage to nonmitigating plaintiffs altogether. This Comment has advocated the former approach, while at least one set of commentators has championed the latter. ${ }^{238}$ To resolve this issue, this Part analyzes the role of mitigating measures in the disability determmation according to the ultimate authority-the statute itself.

Different theories of statutory interpretation place varying weight upon such factors as the language of the statute, legislative intent, and the context in which the legislation was enacted. ${ }^{239}$ However, these three factors, taken together, point to the same conclusion regarding the disability determination under the ADA: Congress intended that an individual who fails to use available mitigating measures be eligible for ADA coverage and that the degree of her inpairment be evaluated in its unmitigated state.

As many commentators have noted, the term "mitigating measures," or its equivalent, does not appear in the text of the ADA. ${ }^{240}$ Although a statute's silence on an issue can suggest many things when it is considered in isolation, the $\mathrm{ADA}$ 's legislative history firmly establishes that Congress was aware of the mitigating-measures issue when it enacted the ADA. Therefore, the statute's silence mdicates Congress' intent to provide ADA protection to individuals who do not use mitigating measures. Committee reports in both the House and the Senate state that the determination of whether an individual has a "disability" within the scope of ADA coverage "should be assessed without regard to the availability of mitigating measures, such as reasonable accommodations or auxiliary aids."241 The House Education and Labor Committee report illustrates this statement by adding, "[f]or example, a person who is hard of hearing is substantially limited in the major life activity of hearing, even though the loss may be corrected through the use of a hearing aid." $" 242$

This strong evidence of legislative intent is further bolstered by the Report of the House Committee on the Judiciary, which states that in determining whether an impairment substantially limits a major life activity, the impairment "should be assessed without considering whether

238. See Meadows and Bales, supra notes 233-37 and accompanying text.

239. See generally William N. Eskridge, Ir. \& Philip P. Frickey, Statutory Interpretation as Practical Reasoning, 42 STAN. L. Rev. 321 (1990); J. Clark Kelso \& Charles D. Kelso, Statutory Interpretation: Four Theories in Disarray, 53 SMU L. REv. 81 (2000).

240. E.g., Amold v. United Parcel Serv., Inc., 136 F. 3d 854, 859 (1st Cir. 1998); Erin K. Barta, Practical Effects of the Sutton Decision: Mitigation, Deference, and the EEOC, 7 TEX. WESLEYAN L. REv. 35, 46 (2000); Eichhorn, supra note 2, at 1092.

241. H.R. REP. No. 101-485, pt. II, at 52 (1990); S. REP. No. 101-116, at 23 (1989).

242. H.R. REP. No. 101-485, pt. II, at 52 (1990). 
mitigating measures, such as auxiliary aids or reasonable accommodations, would result in a less-than-substantial limitation."243 Given that committee reports are considered the most authoritative source for determining legislative intent, ${ }^{244}$ it is evident that Congress intended to provide ADA protection for an individual who is substantially limited in a major life activity even if she chooses not to use mitigating measures that would likely correct her impairment. Consistent with the clear implication of Sutton, these reports also indicate a congressional intention that the disability of such a plaintiff should be evaluated in its current unmitigated state (as opposed to a hypothetical mitigated state).

The inclusion of plaintiffs who do not use mitigating measures in the ADA's protected class is also consistent with the fact that the ADA is a "broad remedial statute." 245 Indeed, a familiar canon of statutory construction is that remedial legislation "should be construed broadly to effectuate its purposes."246 The purpose of the Act is "to provide a clear and comprehensive national mandate for the elimination of discrimination against individuals with disabilities" and "to provide clear, strong, consistent, enforceable standards addressing discrimination against individuals with disabilities. ${ }^{9247}$ As has been noted in other contexts, interpreting the words "individual with a disability" to protect more (rather than fewer) types of people against discrimination is most consistent with these broad remedial goals, especially since such individuals must still prove that they are "qualified" within the meaning of the statute and that there is a causal link between their disability and the adverse employment action. ${ }^{248}$

\section{B. Existing Law Is Sufficient to Protect the Interests of Employers and Employees Who Decide to Mitigate}

Despite Sutton's prohibition on speculation and despite Congress's clear intent, many courts seem determined to deny ADA coverage based on a plaintiff's allegedly inadequate use of mitigating measures. The behavior of such courts is perplexing because often they could have reached the

243. H.R. ReP. No. 101-485, pt. III, at 28 (1990).

244. Thornburg v. Gingles, 478 U.S. 30, 44 n.7 (1986); see also William N. EsKRIDGe \& PhiliP P. Frickey, Cases and Materials on Legislation: Statutes and the Creation of Public Policy 743 (2d ed. 1995).

245. Arnold v. United Parcel Serv., Inc., 136 F.3d 854, 861 (1st Cir. 1998) (citing Penny v. United Parcel Serv., Inc., 128 F.3d 408, 414 (6th Cir. 1997)).

246. Tcherepnin v. Knight, 389 U.S. 332, 336 (1967).

247. 42 U.S.C. $\$ 12101$ (b) (I994).

248. See Arnold, 136 F.3d at 861. In addition, as Part IV.B.3.c will explain, the nonmitigation issue is not likely to arise in a large percentage of ADA cases, and therefore, the interpretation of the disability definition advocated in this paper will not likely implicate the concerns expressed in Sutton about expanding the ADA's coverage to a much larger group of individuals than initially envisioned by Congress. See supra text accompanying notes 157-59. 
same result through a straightforward application of the ADA provisions expressly provided by Congress.

\section{Restrictions and Exemptions that Protect the Interests of Employers}

The ADA protects the interests of employers by restricting the protected class to "qualified individuals with a disability" and by providing exceptions for undue hardship, direct threat, and misconduct stemming from alcohol or drug use.

\section{a. The "Qualified Individual with a Disability" Requirement}

Amidst their fixation on the plaintiff's failure to use mitigating measures, several of the courts discussed in this Comment presented alternate holdings grounded in traditional ADA constructs. Pangalos explicitly held that the plaintiff could not perform the essential functions of his job because he was subject to sudden onslaughts of diarrhea. ${ }^{249}$ The Brookins court found that the plaintiff was not substantially limited in any major life activity, and therefore not disabled. ${ }^{250}$ In Bowers, the court held that the plaintiff was not qualified because he had not identified any reasonable accommodation that would enable him to perform the essential functions of his job. ${ }^{251}$ In Van Stan, the court affirmed summary judgment for the defendant because a reasonable jury could have concluded that the plaintiff's bipolar disorder did not substantially limit any major life activity. ${ }^{252}$ The existence of these alternate holdings demonstrates that these courts could have denied ADA protection to the plaintiffs in question without invoking a "failure to control a controllable disability" doctrine that has no basis in the statute and that might be used to deny ADA protection to those nonmitigating plaintiffs whom Congress intended to include in the statute's protected class.

249. Pangalos v. Prudential Ins. Co. of Am., No. 96-0167, 1996 WL 612469, at *3 (E.D. Pa. Oct. 15, 1996). For discussion of Pangalos, see supra Part II.A.2.

250. Brookins v. Indianapolis Power \& Light Co., 90 F. Supp. 2d 993, 1000-03 (S.D. Ind. 2000). The Brookins court even presented a second alternate basis for its holding: the plaintiff was not qualified because he had identified no reasonable accommodation that would enable him to fulfill his employer's attendance requirement and he could not meet the requirement without an accommodation. Id. at 1000-01. For discussion of Brookins, see supra Part II.C.2.

251. Bowers v. Multimedia Cablevision, Inc., No. CIV.A. 96-1298, 1998 WL 856074, at *4-5 (D. Kan. Nov. 3, 1998). For a more in-depth examination of Bowers, see supra Part ll.A.2.

252. Van Stan v. Fancy Colours \& Co., 125 F.3d 563, 571 (7th Cir. 1997). See supra Part II.A.1 for a more elaborate discussion of Van Stan. 


\section{b. The "Direct Threat" Provision}

Siefken and Burroughs both involved direct-threat situations. ${ }^{253}$ The ADA allows employers to impose job requirements that are "job-related and consistent with business necessity," and it explicitly allows employers to require that their employees do not pose a direct threat to the health or safety of others in the workplace. ${ }^{254}$ In the case of the defendant police departments in Siefken and Burroughs, which had knowledge of the plaintiffs' diabetes when the plaintiffs were hired to serve as police officers, the employers' permissible safety requirement was reflected in a formal expectation that the employees would adequately monitor their diabetes. Moreover, the plaintiffs did not request any accommodations for their disabilities, which likely reflected the fact that no accommodation was needed for them to properly monitor their diseases. ${ }^{255}$ Nevertheless, in both cases, the plaintiffs suffered a severe diabetic reaction that posed a serious risk to the safety of members of the public. Given these facts, it seems that either (l) the plaintiffs' conditions could not be reliably controlled with proper monitoring, in which case they posed a significant safety risk to others and were not "qualified," or (2) the plaintiffs' conditions could be controlled with proper monitoring but the plaintiffs failed to do so, despite the fact that no reasonable accommodations were needed for them to do so, and therefore their failure to monitor their conditions posed a significant safety risk to others such that they were not "qualified" for their jobs as police officers. Thus, despite the fact that subsequent courts like Van Stan and Brookins have cited "the Siefken rule" that a "plaintiff cannot recover under the $\mathrm{ADA}$ if through his own fault he fails to control an otherwise controllable illness," specific application of the ADA's direct-threat provision. ${ }^{257}$

253. Siefken v. Village of Arlington Heights, 65 F.3d 664 (7th Cir. 1995); Burroughs v. Springfield, 163 F.3d 505 (8th Cir. 1998). See supra Part II.A.1 for a detailed description of Siefken and Burroughs.

254. 42 U.S.C. $\$$ I $2113(a)$,(b) (1994).

255. The direct threat provision of the ADA requires that the extent of the risk posed by the plaintiff must be assessed after application of potential accommodations. See id. $\S 12113$ (a). Therefore, if some reasonable accommodation would have prevented the diabetic incidents from occurring, the plaintiffs' eases could not be denied on direct threat grounds. However, given that the plaintiffs did not request any reasonable accommodations, it seems likely that none were needed to enable proper monitoring of their diseases. Moreover, the Siefken court, at least, seems to have considered whether a reasonable accommodation would have aided the plaintiff: "Siefken is not asking for an accommodation; he is not asking the Village to change anything. He is asking for another chance to allow him to change his monitoring technique. But the ADA does not require this." Siefken, 65 F.3d at 666-67.

256. Brookins, 90 F. Supp. 2d at 1006 (citing Van Stan); Van Stan, 125 F.3d at 570 (citing Siefken).

257. See, e.g., Dyrek v. Garvey, No. 00C 6314, 2001 WL 1002471, at *5 (N.D. Ill. Aug. 31, 2001) (citing Siefken for the proposition that "[i]t is not a violation of the ADA or Rehabilitation Act to require an employee in a safety-related position to control his diabetes"). 


\section{c. Misconduct that Severs the Causal Link Between Disability and Discrimination}

For an ADA plaintiff to prevail, the court must find that the adverse employment action was taken "because of" the plaintiff's disability. ${ }^{258}$ This causation determination can be complicated when an individual's failure to comply with treatment regimens is a direct result of the symptoms of her mental disability. ${ }^{259}$ The relationship between symptoms and treatment noncompliance is significant because some courts may view the failure to comply with treatment regimens as a type of misconduct that severs the casual link between disability and discrimination. ${ }^{260}$ In doing so, such courts may ignore the close link between discrimination based on the symptoms of a disability and discrimination based on the disability itself. As the discussion below will demonstrate, the ADA provides courts with clear guidelines about how symptoms leading to misconduct should affect the causation determination.

The text and structure of the ADA suggest a causation exception for direct threat situations. Specifically, the causal link between disability and

258. 42 U.S.C. $\$ 12112(1994)$.

259. See supra notes $197-00$ and accompanying text.

260. This is one explanation for the broad reading of Siefken by courts like Van Stan and Brookins. See supra text accompanying notes 116-21 for a discussion of Van Stan; see supra text accompanying notes 225-30 for a discussion of Brookins. The so-called "misconduct-disability" distinction is a familiar problem in ADA law. It emerges as an issue in cases where an employer claims to have terminated an einployee based on "misconduct" rather than "disability," but the employee argues that the misconduct was caused by the disability, and therefore, that the employer's action is equivalent to acting "because of" the disability. Some courts hold that termination for conduct that has a strong causal connection to the underlying disability should be analyzed in the same way as termination for the disability itself. See, e.g., Den Hartog v, Wasatch Acad., 129 F.3d 1076, 1086-87 (10th Cir. 1997) (emphasizing that "[m]ental illness is manifested by abnormal behavior" and therefore employers must tolerate "certain levels" of disability-caused abnormal behavior); Teahan v. Metro-North Commuter R.R. Co., 951 F.2d 51I, 515-17 (2d Cir. 1991) (a well known Rehabilitation Act case where the plaintiff substance abuser brought suit after being fired for excessive absenteeism, contending that the absenteeism was caused by his substance abuse). Many courts have rejected this approach, however, and instead draw a distinction between the plaintiff's misconduct and the disability: when the adverse employment action is taken "because of" the disability, an ADA violation is found; when it is taken "because of" the misconduct, there is no ADA violation. See, e.g., Despears v. Milwaukee County, 63 F.3d 635, 635 (7th Cir. I995); Maddox v. Univ. of Tenn., 62 F.3d 843, 847 (6th Cir. 1995); Leary v. Dalton, 58 F.3d 748, 753-54 (1st Cir. 1995); Little v. FB1, 1 F.3d 255, 257-59 (4th Cir. 1993); Fritz v. Mascotech Auto. Sys. Group, 1nc., 914 F. Supp. 1481, 1492-94 (E.D. Mich. 1996). Most of the cases taking the latter approach have two distinctive factual features. First, the employee had engaged in "egregious" or criminal misconduct. Fritz, 914 F. Supp. at 1493 (noting that every case cited with approval in Maddox involved an employee engaged in serious or criminal misconduct); see, e.g., Maddox, 62 F.3d at 845 (arrest for driving under the influence of alcohol); Leary, 58 F.3d at 749 (excessive unauthorized absence resulting from mcarceration after arrest for driving while intoxicated and drug possession); Little, 1 F.3d at 257 (FBI agent intoxicated while on duty). Second, the cases often concemed misconduct related to alcohol or drug use. See, e.g., Despears, 63 F.3d at 637 (alcoholism); Maddox, 62 F.3d at 847 (alcoholism); Leary, 58 F.3d at 754 (alcohol and drug addiction); Little, 1 F.3d at 259 (alcoholism). See also Brian T. Rabineau, Note, Those with Disabilities Take Heed: Eighth Circuit Suggests that ADA May Not Protect Those Who Fail to Control a Controllable Disability, 65 MO. L. REV. 319, 331 (2000). 
an adverse employment action can be severed in cases where the employee poses a direct threat to others, even when the misconduct that led to the adverse employment action was a symptom of the disability. ${ }^{261}$ Thus, when the Siefken court stated that the plaintiff's failure to monitor his diabetes was a more immediate cause of his termination than his underlying disability, it was not asserting that the failure to control a controllable disability is a broad category of misconduct that severs the causal link between a plaintiff's disability and the adverse employment action. ${ }^{262}$ Rather, the court was properly invoking the causation exception for direct-threat situations.

Similarly, in Van Stan, ${ }^{263}$ the issue of whether the plaintiff's alleged marijuana use reduced the effectiveness of his bipolar medications was relevant to causation because the ADA states that employers may

hold an employee who engages in the illegal use of drugs or who is an alcoholic to the same qualification standards for employment or job performance and behavior that such entity holds other employees, even if any unsatisfactory performance or behavior is related to the drug use or alcoholism of such employee. ${ }^{264}$

In this way, the ADA expressly severs the causal connection between disability and discrimination when alcohol abuse or drug use is involved. Given this provision, there was no need for the Van Stan court to invoke the broad "failure to control a controllable disability" doctrine.

Thus, in cases of alcohol and drug use and direct threat, Congress explicitly severs the causal connection between disability-related misconduct and an adverse employment action. Significantly, however, the fact that Congress provides these specific exceptions suggests that misconduct in other situations does not sever the causal connection. The court in Den Hartog v. Wasatch Academy suggested as much, stating that a "necessary corollary" to these exceptions is that "certain levels of disability-caused conduct . . . have to be tolerated or accommodated." ${ }^{265}$ As the Den Hartog court eloquently stated, "[m]ental illness is manifested by abnormal behavior, and is in fact normally diagnosed on the basis of abnormal

261. 42 U.S.C. $\$ 12113$ (a)-(b) (1994) states:

It may be a defense to a charge of discrimination under this chapter that an alleged application of qualification standards ... has been shown to be job-related and consistent with business necessity, and such performance cannot be accomplished by reasonable accommodation.... The term 'qualification standards' may include a requirement that an individual shall not pose a direct threat to the health or safety of other individuals in the workplace.

262. See Siefken v. Village of Arlington Heights, 65 F.3d 664, 666 (7th Cir. 1995). The fact that Siefken's discussion of the causation issue cites Despears, see supra note 260, may have led courts like Van Stan and Brookins to erroneously conclude that Siefken's discussion of causation was not limited to direct-threat situations.

263. Van Stan v. Fancy Colours \& Co., 125 F.3d 563, 570 (7th Cir. 1997); see supra text accompanying notes $116-21$.

264. 42 U.S.C. $\S 12114(c)(4)$ (1994).

265. $129 \mathrm{~F} .3 \mathrm{~d}$ at 1087 . 
behavior.... To permit employers carte blanche to terminate employees with mental disabilities on the basis of any abnormal behavior would largely nullify the ADA's protection of the mentally disabled."266

In sum, the ADA already protects the interests of employers by restricting the protected class to "qualified individuals with a disability" and by providing exceptions for undue hardship, direct threat, and misconduct stemming from alcohol or drug use. Given the existence of these congressionally approved concepts, courts need not invent a "failure to control a controllable disability" doctrine that has no basis in the statute.

\section{Individuals Who Mitigate Their Impairments Are Protected by the "Record of" and "Regarded as" Definitions}

Some commentators have asserted that Sutton creates perverse incentives: Individuals who choose to correct their impairments may no longer fall within the ADA's definition of "disability," but those who choose not to use reasonable corrective measures may still be covered by the ADA. ${ }^{267}$ Post-Sutton courts might be tempted to impose a "failure to control a controllable disability" doctrine to avoid this counterintuitive result. ${ }^{268}$ Courts need not manufacture such a doctrine to achieve a just result, however, because individuals who successfully use mitigating measures can still receive ADA protection after Sutton. ${ }^{269}$

First, ADA plaintiffs whose impairments are not substantially limiting in their mitigated state may still receive ADA protection as individuals who have a "record of" disability. ${ }^{270}$ Many individuals with an impairment that is currently mitigated by devices or medication were substantially limited in a major life activity at some point in the past.

266. Id.

267. See, e.g., Eichhorn, supra note 2, at 1111. Eichhorn commented that under Sutton plaintiffs opting not to use mitigating measures will be deemed disabled, while others who suffer identical impairments but opt for treatment will not. This approach is at best counterintuitive because it denies protection against disability discrimination to plaintiffs simply because they have taken active steps to counteract the difficulties imposed by their impairments.

Id.; Erica Worth Harris, Controlled Impairments Under the Americans With Disabilities Act: A Search for the Meaning of "Disability", 73 WASH. L. REv. 575, 600 (1998) (suggesting that some "malingerers" might decline to control their impairments to obtain ADA coverage); Fishman, supra note 17, at 2036, 2039 (stating that it is "inconsistent" to protect nonmitigating plaintiffs while denying ADA protection to mitigating plaintiffs).

268. See, e.g., Rose v. Home Depot U.S.A., Inc., 186 F. Supp. 2d 595, 617 n.8 (D. Md. 2002) (justifying its view that nonmitigating plaintiffs are not members of the ADA's protected class by citing the "inconsistency" of protecting nonmitigating plaintiffs while failing to protect similarly situated mitigating plaintiffs).

269. See, e.g, Burke \& Abel, supra note 16, at 800-01 (noting that the mandated consideration of mitigating measures applics only to the case of a Subsection A disability, and so plaintiffs with controlled disabilities may still be able to establish a violation of the statute under the Subsection B or Subsection $C$ definitions of disability).

270. See supra Part I.A, discussing 42 U.S.C. $\$ 12102(2)(B)(1994)$. 
Second, individuals who cannot establish a "record of" disability, perhaps because they received treatment for a progressive impairment before it reached the substantially limiting stage, ${ }^{271}$ may still be protected against discrimination if they are "regarded as"272 disabled. ${ }^{273}$ For example, a plaintiff whose diabetes is controlled with inedication may still suffer discrimination from an employer who fears that the employee will suffer a diabetic episode in the future. Courts tend to construe the "regarded as" definition of disability narrowly, however. They require a plaintiff proceeding under the "regarded as" definition to prove that the employer has regarded her as "substantially limited in a major life activity."274 This requirement could prove problematic for plaintiffs when the employer's discrimination is based on vague fears rather than on a crystallized belief that the plaintiff is "substantially limited in a major life activity."275

This narrow literal interpretation of the "regarded as" definition of disability seems to conflict with congressional intent. ${ }^{276}$ Committee reports in both the House and the Senate indicate that the "regarded as" definition of disability was intended to encompass employers' negative attitudes, including discrinination based on myths, fears and stereotypes. One House report stated that "a person who is rejected from a job because of the myths, fears and stereotypes" about a disability is covered by the "regarded as" definition of disability. ${ }^{277}$ Similarly, a Senate report stated that a "person who is excluded from any activity covered under this Act or is otherwise discriminated against because of a covered entity's negative attitudes towards disability is being treated as having a disability which affects a major life activity."278

Given this evidence, courts can use the "regarded as" definition of disability to provide ADA protection to individuals who are not substantially limited in a major life activity when they use mitigating measures but who are still discriminated against based on their employers' negative attitudes toward disability. ${ }^{279}$ This solution to possible perverse incentives created by Sutton has a much stronger basis in the statute than the "failure to control a controllable disability" doctrine. It is also consistent with the

271. See Eichhorn, supra note 2, at 1096.

272. See supra Part I.A. discussing 42 U.S.C. $\$ 12102(2)(C)$ (I994).

273. See Bland \& Walsh, supra note 88 , at 23-24.

274. See supra note 54 and accompanying text.

275. See Eichhorn, supra note 2, at 1096-98.

276. Id. at 1089-90.

277. H.R. REP. No. 101-485, pt. III, at 30 (1990).

278. S. REP. No. 101-116, at 24 (I989).

279. As discussed in Part III.A., committee reports are the authoritative source for legislative intent. See supra note 244. 
ADA's status as a "broad remedial statute"280 because it includes more, rather than fewer, individuals within the disability definition. ${ }^{281}$

IV

Critique of Proposals that Courts Should Evaluate the Reasonableness of a Plaintiff's Decision Not to Mitigate

The preceding Part established that plaintiffs who do not use available mitigating measures may still have a "disability" within the meaning of the $A D A$ and that there is no practical need for the "failure to control a controllable disability" doctrine because the ADA already protects the interests of employers and mitigating plaintiffs. Nevertheless, several commentators have contended that it is unfair for employers to bear the burden of accommodating disabled employees who choose not to use available mitigating measures. These commentators have proposed, in various forms, that an employer should not be required to accommodate the disability of a nonmitigating plaintiff unless that plamtiff's decision not to use mitigating measures is "reasonable." These proposals present legal questions distinct from those of the preceding Part because they focus on the statute's reasonable accommodation provision rather than the disability definition, thereby sidestepping the direct reach of Sutton and the clear evidence of Congress's belief that a nonmitigating plaintiff may still have a "disability."

This Part will critique two proposals that contend that the reasonableness of a plaintiff's decision not to mitigate should affect an employer's duty of accommodation. Part IV.A considers a proposal that would balance the burden of mitigation on the plaintiff against the burden of accommodating the plaintiff's unmitigated disability on the employer. Part IV.B evaluates a proposal modeled after the tort doctrine of avoidable consequences that suggests an accommodation is not "reasonable" if an individual with a controllable disability does not take steps "that an ordinarily prudent person would take under the circumstances in an effort to better his condition." $2 \& 2$

\section{A. Balancing the Plaintiff's Burden of Mitigation Against the Employer's Burden of Accommodation}

In the wake of Sutton, Professors Debra Burke and Malcolm Abel have proposed that the burden that mitigation would impose on the plaintiff should be balanced against the burden that an accommodation of the plaintiff's unmitigated disability would impose on the employer. ${ }^{283}$ Under this

280. Amold v. United Parcel Serv., lnc., 136 F.3d 854, 861 (Ist Cir. 1998).

281. See supra Part III.A.

282. Key, supra note 17, at 99.

283. Burke \& Abel, supra note 16, at 813-14. 
approach, the employer would bear the burden of proving that the utilization of a mitigating measure by the employee is a more reasonable solution than requiring the employer to accommodate the unmitigated disability. ${ }^{284}$ For example, in the case of the plaintiff in Pangalos, ${ }^{285}$ the court would have considered whether the plaintiff's use of mitigating measures, such as surgery or a diaper, were more reasonable solutions to his work situation than the accommodations that his employer would have been required to provide for his unmitigated ulcerative colitis. ${ }^{286}$ Burke and Abel suggested several factors that might be relevant to an evaluation of the reasonableness of the plaintiff's decision to not use mitigating measures, including "recommendations of physicians; the cost of the recommended treatment, including insurance coverage; religious objections sincerely held; and the nature and severity of potential side effects and health risks associated with the use of the proposed treatment option, including possible allergic reactions, the potential for long-term addiction, and debilitating effects."287 Burke and Abel, however, did not identify any statutory basis for their proposed approach. Rather, they merely asserted that "[a]n approach to the problem of correctable disabilities that balances the burden on the employer versus the responsibility of the employee is preferable to a categorical classification of a person with a correctable disability as being either qualified or not, or, alternatively, substantially limited or not."288

Burke and Abel were not the first to suggest that the reasonableness of an employee's decision not to use mitigating measures should affect the employer's duty to provide a reasonable accommodation undcr the ADA. In 1996, Professor Lisa Key proposed that if a court finds that it is reasonable for an employee to take a mitigating action, then the employer is not obligated to provide a reasonable accommodation for the employee's unmitigated disability. ${ }^{289}$ Conversely, if a court finds that it is not reasonable to expect the employee to undertake a mitigating action, then the employcr would be required to provide a reasonable accommodation of the employee's unmitigated disability. ${ }^{290}$

Despite some similarities, Burke and Abel's approach is much harsher than Key's proposal. Key's proposal requires only that the plaintiff's decision not to mitigate be reasonable; if the plaintiff's decision is deemed reasonable, then the employer must provide a reasonable accommodation for the plaintiff's unmitigated disability. Burke and Abel's approach, however, requires a second step: even if the employee's decision not to mitigate is

284. Id. at 816.

285. See supra text accompanying notes 122-26.

286. See Burke \& Abel, supra note 16 , at 813.

287. Id. at 814 .

288. Id.

289. Key, supra note 17, at 99-100.

290. Id. at 97 . 
reasonable, the employer may still escape the duty of reasonable accommodation if the burden of the reasonable accommodation on the employer outweighs the burden that the mitigating action would impose on the employee. ${ }^{291}$ Thus, even if an employee's decision not to mitigate is reasonable, the employer still may not be required to provide a reasonable accommodation.

This second step of Burke and Abel's approach presents some obvious problems. Most notably, it brings to mind the familiar adage that "you can't compare apples and oranges." For instance, consider a situation where an employee declines medication for her physical disorder due to a side effect of mild, constant anxiety. How is a court to weigh the burden of mild, constant anxiety on the plaintiff against, for example, the financial cost of a reasonable accommodation for the plaintiff's unmitigated condition? ${ }^{292}$ In addition, even if the proposed analysis can surmount the differences in types of burdens to be compared, Burke and Abel's proposal raises an additional question of whether the employee and employer's respective burdens are evaluated according to the same scale. For example, does the einployer's burden merely have to exceed the plaintiff's burden, or must the employer's burden outweigh the plaimtiff's by some order of magnitude for the employer to be relieved of its statutory duty of reasonable accommodation? ${ }^{293}$

Despite the problems associated with any "balancing" of the plaintiff's and the employer's burdens, this Comment will not undertake a detailed evaluation of the second step of Burke and Abel's approach. Such an evaluation is unnecessary because, as set forth below, Congress intended that the employer's duty of reasonable accommodation be evaluated without reference to the reasonableness of a plaintiff's decision not to mitigate, and therefore, courts can adopt neither the Burke and Abel proposal nor the Key proposal.

291. See Burke \& Abel, supra note 16, at \$13-17 (stating that the employer should be "permitted to establish that, under the circumstances, the utilization of mitigating measures by the employee is a more reasonable alternative to an accommodation by the employer").

292. Although courts regularly place a price tag on pain and suffering in the remedial phase of litigation, the balancing task proposed by Burke and Abel is very different because it would affect the determination of liability. Further, attempting to discern how much money would compensate a plaintiff for a loss is conceptually different than balancing the burden of pain and suffering upon an individual against burdens such as inconvenience or financial cost upon an employer. For instance, although a jury might award twenty million dollars in a wrongful death action, it is unlikely that the decedent would have agreed to die in exchange for twenty million dollars.

293. Courts employing the cost-benefit approach, discussed infra note 326 and accoinpanying text, do seem to evaluate "costs" on a different scale than "benefits." However, this cost-benefit approach is distinct from that of Burke and Abel because it focuses exclusively on the burdens and benefits that have energed as a result of the accommodation, whereas Burke and Abel compare the burdens resulting from employer's accommodation to something external to the employer's accommodation: the employee's earlier decision not to mitigate. 


\section{B. Insertion of an Employee-Focused Reasonableness Test into the Statute's Reasonable Accommodation Requirement}

As stated in the previous discussion, some commentators have proposed that the reasonableness of an employee's decision not to use mitigating measures should affect the employer's duty to provide a reasonable accommodation under the ADA. After presenting the proposal of these commentators in more detail, this Section will use tools of statutory construction to demonstrate that the "reasonableness" of an accommodation does not depend upon an employee's decision not to mitigate. When this lack of statutory support is combined with the fact that the proposed reasonableness test necessarily involves the type of speculation prohibited by Sutton, it is clear that courts should not apply the proposed reasonableness test.

Given that this Comment is primarily concerned with the implementation of the ADA in the courts, it does not undertake a comprehensive policy analysis of the proposed reasonableness test. Such proposals are for Congress to consider, not the courts. Nevertheless, Part IV.B.3 presents a few considerations that weigh against congressional endorsement of the proposed reasonableness test.

\section{The Proposed Reasonableness Test}

In 1996, Professor Lisa Key argued that an accommodation is not "reasonable" if an individual with a controllable disability does not take steps "that an ordinarily prudent person would take under the circumstances in an effort to better his condition." ${ }^{294}$ Although published before Sutton, this proposal is still influential because several post-Sutton commentators have made similar suggestions. ${ }^{295}$ In addition, some might argue that Key's proposal sidesteps the implications of Sutton by focusing on the concept of reasonable accommodation rather than the definition of disability, and by limiting the amount of speculation involved according to the well-established parameters of the doctrine of avoidable consequences, discussed below.

Underlying Key's proposal is the view that it is unfair for an employer to be burdened with the cost and responsibility of making an accommodation for a disability that continues to exist only because an employee chooses not to bear the cost or responsibility of mitigating it. ${ }^{296}$ Key suggested that if courts allow the ADA to cover individuals who fail to

294. Key, supra note 17, at 99 .

295. See, e.g., Burke \& Abel, supra note 16, at 813 (including the reasonableness of an employee's decision not to use mitigating measures as a factor in their balancing test); Fishnan, supra note 17 , at 2033-41 (contending that a nonmitigating plaintiff is not protected by the ADA unless she can provide a substantial justification for not using available corrective measures).

296. Key, supra note 17 , at 82; see also Bland \& Walsh, supra note 88 , at 27. 
mitigate controllable disabilities, the legitimacy of the ADA will be undermined because it will be perceived as helping individuals with "bogus or dubious disabilities" to avoid personal responsibility. ${ }^{297}$ Furthermore, some commentators argue that by requiring employers to make accommodations without reference to an einployee's decision not to mitigate, the ADA removes employees' incentives to mitigate their conditions. ${ }^{298}$

According to Key's proposal, if a court finds that it is reasonable for the employee to undertake a mitigating action, then the only accommodation that the employer should be required to make would be one that is necessary to allow the employee to take the mitigating action. ${ }^{299}$ Conversely, if a court finds that it is not reasonable to expect the einployee to undertake a mitigating action, then the einployer would be required to make a reasonable accommodation within the current parameters of the $\mathrm{ADA}^{300}$ Finally, Key suggested one exception to add flexibility to this general scheme: if it is reasonable to expect the employee to undertake the mitigating action but there is also a viable accommodation the employer could make for the employee's unmitigated disability, then the employee who chooses to forgo the mitigating action could require the employer to provide accommodation for the unmitigated disability, but at the employee's cost. ${ }^{301}$

Key borrowed concepts from the tort doctrine of avoidable consequences to develop a specific approach for determining whether it is reasonable for an employee to mitigate a disability.$^{302}$ Under the doctrine of avoidable consequences, an injured person cannot recover damages for consequences of an injury that a reasonably prudent person would have taken steps to avoid. ${ }^{303}$ Based on this doctrine, Key emphasized that the

297. Key, supra note 17 , at 80 .

298. Harris, supra note 267 , at 600 ; Key, supra note 17 , at 84 .

299. Key, supra note 17, at 97. For example, if the court in Pangalos v. Prudential Insurance Co. of America (see supra text accompanying notes 122-26) had concluded that it was reasonable for the plaintiff to undergo surgery for his ulcerative colitis, then Key would only require the plaintiff's employer to accommodate the plaintiff's surgery, such as by allowing the plaintiff to work a reduced schedule while he recovers.

300. Id. at 97 .

301. Id. at 97-98. Of course, this exception assumes that the costs associated with the accommodation are of a type that can be easily quantified. However, some accommodations may involve operational costs-such as inconvenience to others or loss of efficiency for others-that are not easily reduced to a monetary number.

302. Id. at 98-99.

303. Jacob A. Stein, Stein on Personal Injury Damages $§ 18: 4$ (3d cd. 1997 \& Supp. 2000). Whether the plaintiff has acted reasonably in avoiding damages is a question of fact. JACK K. LEVIN ET AL., AMERiCaN JURISPRUDENCE $\$ 498$ ( $2 \mathrm{~d}$ ed. 1988 \& Supp. 2001). The defendant bears the burden of proof regarding the plaintiff's failure to mitigate. STEIN, supra, at $\S 18: 6$. Factors relevant to the reasonableness of a plaintiff's decision include the probability that the treatment will be effective, the cost of treatment, the inconvenience resulting froin treatment, additional risks associated with treatment, and whether the treatment was recominended by a medical expert. Id. at $\S 18: 4$. Courts 
reasonableness determination must take into account the totality of the circumstances, ${ }^{304}$ and that the plaintiff should not be "required to accept great risks, undertake heroic measures, or accept great personal sacrifices." 305 She identified several factors that should be considered in the reasonableness analysis, including the risk involved in taking the mitigating action, the pain involved, the amount of effort involved, the probability that the mitigating action will be successful in improving or eliminating the disability, and the monetary cost. ${ }^{306}$ These considerations are then balanced against "the consequences of not taking the mitigating action." 307

Key also recognized some of the controversial issues likely to arise under her reasonableness test, such as what to do when the mitigating measure involves surgery, medication, or lifestyle changes. Key acknowledged that "greater scrutiny" is required when the mitigating action involves surgery because "surgery is more likely to involve significant risk, pain, and expense." 308 She emphasized that courts have frequently encountered the issue of surgery as a mitigating measure in personal injury cases and that generally it is not unreasonable for an individual to refuse surgery if there is "more than a slight risk that the surgery will result in death, an aggravation of the existing condition, or the development of a new health problem." 309 She also argued, however, that it would be unreasonable for an individual to refuse to undergo a "simple and safe" surgical operation. ${ }^{310}$

Key stated that a plaintiff's refusal to take prescribed medication would be reasonable in "extraordinary situations," such as when the medication is likely to cause severe side effects. ${ }^{311} \mathrm{Key}$ 's approach to this issue, however, is more extreme than the approach suggested by Burke and Abel. Consistent with Sutton's emphasis on side effects, Burke and Abel suggested that courts should consider the nature and severity of potential side effects and the health risks associated with the proposed treatment, ${ }^{312}$ but their discussion did not imply that refusal of prescribed medication would only be reasonable in "extraordinary situations."

Finally, Key considered mitigating measures that involve lifestyle changes, such as when a doctor recommends that a patient's impairment

applying this doctrine have held that a plaintiff may not be required to subject himself to surgical or nonsurgical medical procedures that present a risk of additional injury, may not be asked to violate his beliefs to mitigate damages, and may not be penalized for the failure to seek treatment when the plaintiff does not recognize the need for such treatment. Id.

304. Key, supra note 17, at 97.

305. Id. at 98 .

306. Id. at 99 .

307. Id.

308. Id. at 101 .

309. Id.

310. Id. at $101-02$.

311. Id. at $100-01$.

312. Burke \& Abel, supra note 16 , at 814 . 
will improve if she loses weight or quits smoking. ${ }^{313}$ Key suggested that the plaintiff must make "a reasonable effort" to comply with the doctor's recommendation, but that the reasonableness determination will not turn on whether the individual is ultimately successful or not. ${ }^{314}$ Here again, however, Burke and Abel took a more moderate position than Key. ${ }^{315}$ They suggested that courts should seriously consider the employee's individual autonomy with respect to lifestyle changes such as recommended diet and exercise programs, programs to stop smoking, and even a doctor's recommendation to "take it easy." 316

\section{Courts' Lack of Statutory Authority to Implement an Employee- Focused Reasonableness Test}

At the heart of Key's proposal is the significance of the word "reasonable" in the term "reasonable accommodation." Although the Supreme Court has indicated that the term "reasonable" modifies "accommodation" in some significant way, ${ }^{317}$ no explicit definition of "reasonable" can be found in the statute. ${ }^{318}$ The ADA defines "reasonable accommodation" only by example: "job restructuring, part-time or modified work schedules, reassignment to a vacant position, acquisition or modification of equipment or devices, appropriate adjustment or modifications of examinations, training materials or policies, [and] the provision of qualified readers or interpreters." 319

Given the statute's silence regarding the meaning of "reasonable," Key offered a plain-language interpretation. According to Key, "generally when the term 'reasonable' is used, it is meant to weaken the duty required ... The ADA, therefore, does not require employers to make every conceivable accommodation. Rather, their obligation is something less." "320 Based on this observation, Key proposed that an accommodation is not "reasonable" if a disabled individual "refuses or fails to take reasonable steps to improve or eliminate the condition." 321

313. Key, supra note 17 , at 102-03.

314. Id. at 103.

315. Despite their more moderate approach to the "reasonableness" determination, the balancing portion of Burke and Abel's test is arguably much harsher than Key's proposal. See supra Part IV.A.

316. Burke \& Abel, supra note 16, at 815 .

317. US Airways, Inc. v. Bamett, 122 S. Ct. 1516, 1522-23 (2002).

318. See Paul Steven Miller, Disability Civil Rights and a New Paradigm for the Twenty-First Century: The Expansion of Civil Rights Beyond Race, Gender, and Age, 1 U. PA. J. LAB. \& EMP. L. 511,519 (1998) (noting that reasonableness is a "term of art that Congress defined only through examples of changes or modifications to be made or items to be provided to a qualified individual with a disability").

319. 42 U.S.C. $\$ 12111(9)(B)$ (1994).

320. Key, supra note 17 , at 95 .

321. Id. at 96 . 
The controversial aspect of Key's proposal is not her view that the word "reasonable" softens the employer's duty of accommodation. ${ }^{322}$ Indeed, in a recent case, US Airways, Inc. v. Barnett, the Supreme Court considered the meaning of the word "reasonable" in the term "reasonable accommodation." 323 Although the Court did not provide a definition of the word "reasonable," it did conclude that a "reasonable accommodation" means something more than merely an "effective accommodation." 324 For example, the Court explained that an accommodation that would effectively address a disabled individual's limitations might nonetheless be unreasonable because of its impact on other employees. ${ }^{325}$

What is controversial about Key's proposal is her view that the term "reasonable" suggests an evaluation of the employee's actions. This view stands in marked contrast to the interpretations of other courts, which construe the term "reasonable" only to involve an analysis of the effects of the accommodation. For example, some lower courts have suggested that an accommodation is not "reasonable" when the costs of the accommodation are "clearly disproportionate" to the benefits of the accommodation. ${ }^{326}$

322. Many lower courts have held similar views. See, e.g., Reed v. LePage Bakeries, lnc., 244 F.3d 254, 259 (1st Cir. 2001)

Indeed, simply in explaining how her proposal constitutes an 'accommodation,' the plaintiff must show that it would effectively enable her to perform her job .... But what plaintiff must show further under the statute is that her requested accommodation is 'reasonable.' And consistent with its usage throughout the law, the concept of reasonableness here constrains the plaintiff in what she can demand from the defendant.

Id.; Vande Zande v. Wis. Dep't of Admin., 44 F.3d 538, 542 (7th Cir. 1995) ('“[R]easonable' may be intended to qualify (in the sense of weaken) 'accommodation,' in just the same way that if one requires a 'reasonable effort' of someone this means less than the maximum possible effort, or in the law of 'reasonable care,' ... requires something less than the maximum possible care.");.

323. 122 S. Ct. 1516, 1522-23 (2002) (considering whether a disabled employee's requested accommodation is "reasonable" within the meaning of the statute when it presents a possible conflict with an employer's seniority system).

324. Id. at 1523 .

325. Id. at 1522 .

326. E.g., Gaul v. Lucent Techs., Inc., 134 F.3d 576, 580-81 (3d Cir. 1998); Vande Zande, 44 F.3d at 542; Murray v. Surgieal Specialties Corp., No. CIV.A.97-0444, 1999 WL 46583, at *5 (E.D. Pa. Jan. 14, 1999); Sicoli v. Nabiseo Biscuit Co., No.CIV.A.96-6053, 1998 WL 297639, at*9 (E.D. Pa. June 8, 1998); see also Andress v. Nat'l Pizza Co. Intern., 984 F. Supp. 475, 485 (S.D. Miss. 1997). The Vande Zande court used the following rationale to distinguish the role of cost eonsiderations in the reasonable accommodation analysis from the undue hardship analysis: "Even if an employer is so large or wealthy ... that it may not be able to plead 'undue hardship,' it would not be required to expend enormous sums to bring about a trivial improvement in the life of a disabled employee." Vande Zande, 44 F.3d at 542-43. For instanee, in Vande Zande, the court held that it was not reasonable for the employer to be required to spend between $\$ 150$ and $\$ 2000$ so that the wheelchair-bound plaintiff could reach the sinks in the kitchenette area when she eould already use a bathroom sink nearby. Id. at 546 . However, these courts have not asserted that an employer must receive a benefit commensurate with the cost of the accommodation for the aceommodation to be reasonable. See id. at 542,546 ("It would not follow ... that an accommodation would have to be deemed unreasonable if the cost exceeded the benefit however slightly. But, at the very least, the cost could not be disproportionate to the benefit."). As explained in a Rehabilitation Aet case widely cited for the view that "reasonable" implies some type of cost-benefit analysis, 
According to these courts, the term "costs" includes financial and administrative burdens imposed by the accommodation, ${ }^{327}$ and the term "benefits" includes improvement $m$ the situation of the disabled individual (with the pre-accommodation situation serving as a baseline for the coinparison) ${ }^{328}$ and gains achieved by the employer by enabling the employee to work. ${ }^{329}$ This approach stands in marked contrast to Key's proposal, which does not focus on the effects of the accommodation at all, but instead focuses on the reasonableness of a decision made by the employee.

The Supreme Court's reasoning in Barnett supports the view that the reasonableness analysis should be limited to an analysis of the effects of an accommodation. As discussed in Part I, the ADA expressly limits an employer's obligation to provide a reasonable accommodation in only one instance: when the accommodation would pose an "undue hardship" on the employer. ${ }^{330}$ In Barnett, the plaintiff argued that the term "reasonable" must mean only "effective," because otherwise the statute's "reasonable accommodation" and "undue hardship" provisions would be redundant. ${ }^{331}$ In rejecting this view, the Court emphasized that the undue-hardship analysis considers the impact of the accommodation on the einployer, whereas

"a demand for an effective accommodation could prove unreasonable because of its impact, not on business operations, but on fellow employees-say because it will lead to dismissals, relocations, or modification of employee benefits to which an employer, looking at the matter from the perspective of the business itself, may be relatively indifferent." ${ }^{332}$

In this way, the Supreme Court indicated that the distinction between the reasonableness analysis and the undue hardship analysis is that the latter focuses on the impact of the accommodation on the employer, whereas the former may focus on the impact of the accommodation on other employees. Thus, like the lower courts discussed above, the Supreme Court described the reasonableness analysis as mvolving an evaluation of the impact of the accommodation. At no point does the Court's discussion

Section 504 does not require that the employer receive a benefit commensurate with the cost of the accommodation.... [T] he requirement of reasonable accommodation anticipates that it may cost more to obtain that level of performance from an employee with a disability than it would to obtain the same level of performance from a non-disabled employee.

Borkowski v. Valley Cent. Sch. Dist., 63 F.3d 131, 138 (2d Cir. 1995).

327. Gaul, 134 F.3d at 581; see also Murray, 1999 WL 46583, at *5; Sicoli, 1998 WL 297639, at $=9$.

328. Vande Zande, $44 \mathrm{~F} .3 \mathrm{~d}$ at 543.

329. Borkowski, 63 F.3d at 138.

330. 42 U.S.C. $\$ 12112$ (b)(5)(A) (1994). Unless an employer can demonstrate such an undue hardship, the failure to provide a reasonable accommodation constitutes unlawful discrimination. Id. Undue hardship is defined as "an action requiring significant difficulty or expense" when considered in light of several factors set forth in the statute. Id. $\$ 12111(10)$.

331. US Airways, Inc. v. Barnett, 122 S. Ct. 1516, 1522 (2002).

332. Id. 
seem to support Key's assertion that the analysis should be expanded to include an evaluation of the employee's personal decisions that led to the need for an accommodation. ${ }^{333}$

When one considers the statute as a whole, ${ }^{334}$ Key's view that an individual's nonuse of mitigating measures can relieve an employer of its duty of accommodation is further undermined. First, despite the fact that the statute explicitly provides several exceptions ${ }^{335}$ and defenses, ${ }^{336}$ it provides no exception or defense based on an individual's inadequate use of mitigating measures. This statutory silence is especially significant given that Congress was aware of the nonmitigation issue when it enacted the ADA. ${ }^{337}$ Second, although the term "reasonable" is not defined in the $\mathrm{ADA}$, the statute does identify several factors that courts should consider in determining whether an accommodation would impose an undue hardship on an employer. ${ }^{338}$ Although the list is not exhaustive, ${ }^{339}$ none of the enumerated factors concern the employee's behavior. ${ }^{340}$ Rather, the factors listed in the statute primarily implicate the financial or operational burdens that the accommodation would impose on the employer. ${ }^{341}$ Thus, if

333. It should be noted, however, that the Barnett Court's description of the reasonableness analysis was probably influenced by the facts of the Barnett case itself, which considered whether an accommodation is "reasonable" when it presents a possible conflict with an employer's seniority system. Given that a seniority system was involved in the case, it was natural for the Barnett Court to cmphasize the effects of an accommodation on other employees when it discussed the reasonableness analysis. On different facts, the Court might expand its description of the reasonableness analysis to include other considerations.

334. A maxim of statutory interpretation is that courts must consider the meaning of terms in the context of the statute as a whole. Beecham v. United States, 51 I U.S. 368, 372 (1994) (stating that courts must focus on "the plain meaning of the whole statute, not of isolated sentences"); Kokoszka v. Belford, 417 U.S. 642, 650 (1974); see also EsKRIDGE \& FRICKEY, supra note 244, at 643-45.

335. 42 U.S.C. $\S 12111(5)$ (1994) (excepting the United States and a bona fide private membership club from the definition of the term "employer"); id. §12114 (excepting employees who currently engage in the illegal use of drigs from the definition of a "qualified individual with a disability").

336. Id. § 12113(a) (providing that "[i]t may be a defense to a charge of discrimination... that an alleged application of qualification standards, tests, or selection criteria that screen out ... an individual with a disability has been shown to be job-related and consistent with business necessity, and such performance cannot be accomplished by reasonable accommodation ..."); id. $\S 12113$ (b) (providing the direct threat defense); $i d$. $\S 12113(\mathrm{c})$ (permitting religious groups to preferentially employ individuals of a particular religion); id. $\S 12113$ (d) (permitting an employer to refuse to assign an individual with certain infectious or communicable diseases to a job involving food handling when the risk of transmission to others cannot be eliminated by reasonable accommodation).

337. See supra text accompanying notes $241-44$, discussing relevant House and Senate committee reports.

338. 42 U.S.C. $\$ 12111(10)(1994)$.

339. Lavia v, Pa. Dep't of Corr., 224 F.3d 190, 197 n.7 (3d Cir. 2000).

340. See 42 U.S.C. $\$ 12111(10)(B)$ (1994).

341. See id. The list of factors provided in the statute is as follows:

(i) the nature and cost of the accommodation needed ...;

(ii) the overall financial resources of the facility or facilities involved in the provision of the reasonable accommodation; the number of persons employed at such facility; the effect on 
Congress had intended the word "reasonable" to entail a critical analysis of a plaintiff's actions, one would expect that Congress would have made the distinction between the reasonableness analysis and the undue hardship analysis clearer by enumerating factors for the reasonableness analysis as well. Congress did not do so, however, despite its awareness of the nonmitigation issue.

The EEOC's “enforcement guidance"342 regarding the concepts of "reasonable accommodation" and "undue hardship" also supports the view that an $\mathrm{ADA}$ plaintiff's nonuse of mitigating measures does not relieve an employer of its duty to provide a reasonable accommodation. The ADA grants the EEOC authority to issue regulations to carry out the employment provisions in Title I. ${ }^{343}$ As an opinion of the EEOC, the enforcement guidance "constitute[s] a body of experience and informed judgment to which courts and litigants may properly resort for guidance." 344 Question 37 of the enforceinent guidance on reasonable accommodation and undue hardship asks:

Is an employer relieved of its obligation to provide reasonable accommodation for an employee with a disability who fails to take medication, to obtain medical treatment, or to use an assistive device (such as a hearing aid)?

No. The ADA requires an employer to provide reasonable accommodation to remove workplace barriers, regardless of what

expenses and resources, or the impact otherwise of such accommodation upon operation of the facility;

(iii) the overall financial resources of the covered entity; the overall size of the business of a covered entity with respect to the number of its employees; the number, type, and location of its facilities; and

(iv) the type of operation or operations of the covered entity, including the composition, structure, and functions of the workforce of such entity; the geographic separateness, administrative, or fiscal relationship of the facility or facilities in question to the covered entity.

Id.

342. E.E.O.C., ENFORCement Guidance: Reasonable Accommodation and Undue HARDShIP UNDER THE AMERICANS WITH Disabilities ACT (March 1999), at http://www.eeoc.gov/docs/accommodation.html (last visited October 1,2002) (on file with the author) [hereinafter GUIDANCE].

343. 42 U.S.C. $\$ 12116$ (1994); see also Sutton v. United Air Lines, Inc., 527 U.S. 471,478 (1999). The EEOC regulations were not authoritative in Sutton because the definition of disability is contained in a general definitional section of the Act that falls outside of Title 1. Id. at 479. The reasonable accommodation and undue hardship provisions ( $\$ \$ 12111-12112$ ), however, are contained in Title $1(\$ \$ 12111-12117)$ and therefore are subject to EEOC authority.

344. Theodore W. Wern, Note, Judicial Deference to EEOC Interpretations of the Civil Rights Act, the ADA, and the ADEA: Is the EEOC a Second Class Agency?, 1999 Oнाо ST. L.J. 1533, 1576 (quoting Skidmore v. Swift, 323 U.S. 134, 140 (1994)); see also Sutton, 527 U.S. at 502 (Stevens, J., dissenting) (asserting that Skidmore deference should be given to the EEOC's interpretations of the ADA). EEOC enforcement guidance is not entitled to full Chevron deference because it does not constitute a "legislative regulation." Wern, supra, at 1575 (referring to the standard articulated in Chewron U.S.A., Inc., v. Natural Res. Def. Council, Inc., 467 U.S. 837, 844 (1984)). 
effect medication, other medical treatment, or assistive devices may have on an employee's ability to perform the job. ${ }^{345}$

Thus, consistent with the structure of the ADA, the expert opinion of the EEOC is that an employer must provide a reasonable accommodation to an employee who is a qualified individual with a disability even if that employee has chosen not to use available mitigating measures.

Given this evidence derived from the ADA's structure and the EEOC's guidelines, it is not surprising that proponents of Key's position have not found strong support in the statute itself. ${ }^{346}$ In addition to her weak plain-language argument about the meaning of "reasonable," 347 Key attempted to tie her proposal to congressional intent by stating that "Congress did not intend the ADA to relieve persons with disabling conditions of personal responsibility." ${ }^{238}$ She supported this view by citing a congressional finding that "individuals with disabilities are a discrete and insular minority who have been... [discriminated against] based on characteristics that are beyond the control of such individuals and resulting from stereotypic assumptions . . ." 349 Key interpreted the phrase "based on characteristics that are beyond the control of such individuals" to suggest that there is no protection against discrimination based on characteristics that can be controlled with mitigating measures. However, there is more than one plausible interpretation of this statutory language. Given that the phrase "beyond the control" modifies the word "characteristics," the correct interpretation hinges on the meaning of the word "characteristics." On the one hand, Congress could be referring to characteristics that stem from the disability, such as the symptoms and manifestations of the disability that can be controlled in some instances with mitigating measures. Alternatively, Congress could be referring to characteristics that lead to a perception that someone is disabled-whether that perception is based on current impairment, past impairment, or imagined impairment. Since the statutory disability definition includes individuals who are "regarded as" disabled by their employers and who have a "record of" disability, ${ }^{350}$ the latter view of the term "characteristics" is most plausible. Significantly, the characteristic of having had an impairment in the past or of being mistakenly perceived as disabled in the present are beyond an individual's control regardless of whether or not she currently employs mitigating measures. ${ }^{351}$ Lastly, if

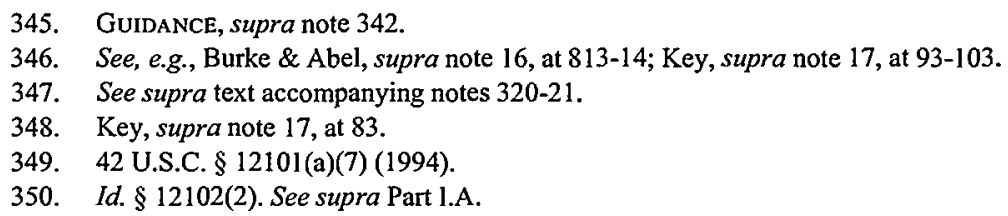

345. GUIDANCE, supra note 342.

346. See, e.g., Burke \& Abel, supra note 16, at 813-14; Key, supra note 17, at 93-103.

347. See supra text accompanying notes 320-21.

348. Key, supra note 17 , at 83.

349. 42 U.S.C. $\$ 12101$ (a)(7) (1994).

350. Id. \$ 12102(2). See supra Part l.A.

351. For instance, a schizophrenic whose symptoms are alleviated by medication may still be perceived as disabled due to social stigma associated with her illness, and a person whose ulcerative colitis was cured with surgery still has a history of ulcerative colitis. 
Congress had intended the phrase "beyond the control" to have the import Key suggests, then it is difficult to imagine why Congress, which was aware of the nonmitigation issue, did not expressly incorporate a "degree of control" requirement into the statute.

Finally, proponents of the reasonableness test assert that the factors incorporated into the reasonableness analysis are consistent with the individualized inquiry demanded by the Court in Sutton. ${ }^{352}$ However, the consideration of such factors will necessarily require courts to speculate about the severity of the plaintiff's impairment and the physical, emotional, and financial costs that would be involved in achieving a mitigated state. As the discussion in Part II demonstrated, such speculation is "contrary to both the letter and the spirit of the ADA." 353 While the doctrine of avoidable consequences may be appropriate and useful in the tort context, it has no place in a statutory scheme that prohibits a speculative analysis of the plaintiff's condition.

In conclusion, Key's arguments, which are based on ambiguous plainlanguage readings, cannot justify an interpretation of the statute that is improbable when one considers the statute as a whole, Supreme Court precedent, EEOC guidelines, and Sutton's prohibition on speculative analysis. Against this legal backdrop, any court that imposes such a reasonableness test on nonmitigating plaintiffs would be legislating rather than adjudicating.

\section{Considerations Weighing Against Congressional Enactment of the Proposed Reasonableness Test}

Proponents of a reasonableness test might argue that if courts lack the authority to impose the test, then Congress should. This Subsection explains why legislators should not incorporate the proposed reasonableness test into the ADA.

Underlying the proposed reasonableness test is the principle that employers should not have to bear the cost of an accommodation that exists solely because an employee has ignored her personal responsibility to mitigate it. To some extent, this personal responsibility rationale has normative appeal. The ancient Greeks believed that citizens had an obligation to inamtain their physical and mental health at the highest level possible. Modern sociologists have argued that the social contract that relieves people of responsibilities when they are sick requires that they cooperate with treatment to become productive members of society as soon as possible. ${ }^{354}$

352. Burke \& Abel, supra note 16 , at 815 .

353. Sutton v. United Air Lines, Inc., 527 U.S. 471, 484 (1999).

354. See Robert D. Miller, Patient Responsibilities: The Other Side of the Coin, 17 T.M. Cool.EY L. REv. 91, 97-98 (2000) (comparing the Greek concept of "natural inherent rights that included responsibilities" and modern sociologist Talcott Parsons's "sick role" concept). 
Similarly, the tort doctrine of avoidable consequences provides that a plaintiff's damages should be reduced to the extent that losses could have been avoided through reasonable efforts. ${ }^{355}$ The idea that people should be discouraged from wasting resources seems to underlie each of these philosophies.

Despite the natural appeal of a policy that encourages personal responsibility and efficient use of resources, the following discussion will demonstrate that several considerations weigh against congressional endorsement of the proposed reasonableness test. ${ }^{356}$

\section{a. Problems with Second-Guessing the Personal Medical Decisions of Disabled Individuals}

Guidance from the Supreme Court indicates that the ADA should not be used to police the treatment decisions of disabled individuals. In Bragdon v. Abbott, the Court considered whether the female plaintiff was substantially limited in the major life activity of reproduction due to her HIV-positive status. ${ }^{357}$ Despite evidence that antiretroviral therapy can reduce to as low as $8 \%$ the risk of perinatal transmission of HIV to an unborn fetus, the Court rejected the argument that the plaintiff was not substantially limited in reproduction because the difficulties associated with reproduction were not insurmountable. ${ }^{358}$ The Court explained:

Conception and childbirth are not impossible for an HIV victim but... $[t]$ he decision to reproduce carries economic and legal consequences as well. There are added costs for antiretroviral therapy, supplemental insurance, and long-term health care for the child who must be examined and, tragic to think, treated for the infection.... In the end, the disability definition does not turn on

355. See Key, supra note 17 , at 98.

356. Additional considerations weigh against the proposed reasonableness test but are not mentioned in the main text because they exceed the scope of this Comment. For instance, imposing a duty of reasonable accommodation upon employers even when it might be more efficient for an employee to use a mitigating measure may be justified because the standard operations of most employers, although rationally adopted, have created barriers to individuals with disabilities. This perspective views "disability" as a social construction. In other words, disability is not a problem that exists within the individual, but rather, disability exists because of the barriers created by a society that rationally caters to the needs of the non-disabled majority. See Wendy E. Parmet, Plain Meaning and Mitigating Measures: Judicial Interpretations of the Meaning of Disability, 21 BERKELEY 1. EMP. \& LAB. L. 53, 56-57 (2000). This view highlights the circularity of a rule that proposes to alleviate the burden of an accommodation on the employer because it will be less burdensome for a disabled individual to use a mitigating measure. Specifically, the expense associated with a reasonable accommodation is created by the employer's rational choice to cater to the non-disabled majority, not by the plaintiff's choice to decline available mitigating measures. Given that the employer benefits over time by efficiently catering to the needs of the non-disabled majority, it does not seem unfair for the burden of accommodation on the employer to outweigh the alternative burden on the ADA plaintiff in isolated cases.

357. 524 U.S. 624,631 (1998).

358. Id. at 640-41. 
personal choice. When significant limitations result from the impairment, the definition is met even if the difficulties are not insurmountable. ${ }^{359}$

The clear implication of this statement is that the medical decisions of disabled individuals are personal and should not be questioned by the courts.

This view of medical decisions as a personal matter is consistent with the respect for individuality and autonomy that is a central value in our society and in our legal system. ${ }^{360}$ The common-law doctrine of self-determination has long recognized an individual's right to control her own body without interference by others. ${ }^{361}$ In addition, the modern informed-consent doctrine reflects the common-law emphasis on decisional autonomy and self-determination. ${ }^{362}$ This doctrine requires a doctor to disclose fully to her patient the material risks and possible alternatives to a proposed medical procedure. ${ }^{363}$ However, "once this information has been disclosed, that aspect of the doctor's expert function has been performed. The weighing of [the] risks against the mdividual subjective fears and hopes of the patient is not an expert skill. Such evaluation and decision is a nonmedical judgnient reserved to the patient alone."364

Given the importance of personal autonomy in medical decisionmaking, courts should not be permitted to judge the "reasonableness" of an ADA plaintiff's decision not to use mitigating measures. As Tangires and Pangalos illustrate, emotional factors and personal preferences often guide decisions about medical treatment and corrective devices. ${ }^{365}$ However,

359. Id. at 641 .

360. See Bruce A. Arrigo \& Jeffrey J. Tasca, 23 Law \& Psychol. Rev. 1, 6 (1999) (noting that "the doctrine of the right to refuse treatment can be traced back to its ancestry in the common law right of autonomy and self-determination"); S. Elizabeth Wilborn Malloy, Beyond Misguided Paternalism: Resuscitating the Right to Refuse Medical Treatment, 33 WAKE FoREST L. REv. 1035, 1043 (1998) (discussing the importance of personal autonomy and the right to refuse treatment).

361. Arrigo \& Tasca, supra note 360 , at 6; Malloy, supra note 360 , at 1036 . As stated by the Supreme Court in 1891, "No right is held more sacred, or is more carefully guarded, by the common law, than the right of every individual to the possession and control of his own person, free from all restraint or interference of others, unless by clear and unquestionable authority of law." Union Pac. Ry. v. Botsford, 141 U.S. 250, 251 (1891).

362. Martha Matthews, Suicidal Competence and the Patient's Right to Rcfuse Lifesaving Treatment, 75 CALIF. L. REv. 707, 721-22 (1987).

The right of bodily self-determination as expressed in the informed consent doctrine can be interpreted as protecting two interests: the interest in being free from nonconsensual bodily invasion and the interest in decision-making autonomy. The first interest concerns the limits of medical and institutional control over the patient's body; the second, the extent of the patient's authority to make health care decisions independently.

Id.

363. Malloy, supra note 360 , at 1045.

364. Cobbs v. Grant, 502 P.2d 1, 10 (Cal. 1972).

365. Tangires v. Johns Hopkins Hosp., 79 F. Supp. 2d 587, 596 (D. Md. 2000) (plaintiff refused treatment based on her "unsubstantiated" fear that steroids would adversely affect another medical condition); Pangalos v. Prudential Ins. Co. of Am., No. 96-0167, 1996 WL 612469, at *1, 3 (E.D. Pa. Oct. 15, 1996) (plaintiff refused to wear a diaper for his ulcerative colitis because it would require him to sit in his own excrement, and plaintiff was not willing to consider the "drastic alternative" of 
rather than acknowledge the importance of an emotion that would lead an individual to endure soiling himself on a daily basis rather than face surgery or a diaper, as in Pangalos, courts implementing the proposed reasonableness analysis may deny ADA coverage to nonmitigating plaintiffs because their fears are "unsubstantiated" 366 and their decisions are unreasonable from the perspective of a nondisabled judge. It is difficult to see how the ADA's goals of "equality of opportunity, full participation, [and] independent living"367 could be met if the statute were to require that disabled individuals conform their personal medical decisions to the views of a nondisabled judge.

Although the preceding discussion establishes that disabled individuals should be protected by the ADA even when their decisions appear irrational, it should be noted that the implementation of a reasonableness analysis could lead to the denial of ADA coverage even when the plaintiff's nonmitigation decision is rational. For example, in Franklin v. U.S. Postal Service, the plaintiff, who suffered from paranoid schizophrenia, failed to take her medication. ${ }^{368}$ The court described the plamtiff's disability as voluntary - one created by the plaintiff's decision not to take her medication. The court stated that " $[t]$ he choice being hers, it seems difficult if not impossible to understand why the actions of the defendant should be deemed to be discriminatory." 369 Significantly, the Franklin court's harsh attitude toward the plaintiff's decision was not tempered by evidence in the record that this choice may have been prompted by the severe side effects of the medication. According to the court, the plaintiff had previously stated to a clinical psychologist that she would not take antipsychotic medication because it stopped her menstruation, interfered with her eyesight, and "messed up" her body. ${ }^{370}$ In other words, the court did not consider the rationality of the plaintiff's decision to refuse medication. This case suggests that one danger inherent in the proposed reasonableness test is that courts are often subject to the very same "stereotypic assumptions" about disabled individuals that Congress sought to combat, ${ }^{371}$ and thus some courts may not perceive the rationality of a plaintiff's decision not to use mitigating measures. In this way, the subjective nature of the reasonableness determination threatens to undermine the statute's goal of "clear, strong, consistent, enforceable" standards. ${ }^{372}$

surgery). For a detailed discussion of Tangires, see supra Part II.C.I. For a detailed discussion of Pangalos, see supra Part II.A.2.

366. Tangires, 79 F. Supp. $2 d$ at 596.

367. 42 U.S.C. $\$ 12101$ (a)(8) (1994).

368. 687 F. Supp. 1214 (S.D. Ohio 1988) (a Rehabilitation Act case). See supra Part II.A.1.

369. Franklin, 687 F. Supp. at 1218.

370. Id. at 1217 .

371. 42 U.S.C. $\$ 12101(\mathrm{a})(7)(1994)$.

372. Id. $\$ 12101(\mathrm{~b})(2)$. 


\section{b. Inappropriateness of the Tort Doctrine of Avoidable Consequences in the ADA Context}

To address difficult issues of valuation and balaneing, the proposed reasonableness test draws on the concepts developed by courts in applying the tort doctrine of avoidable consequences. The doctrine of avoidable consequences, however, does not defeat the plaintiff's claim; rather, it only affects the amount of damages that a plaintiff may recover. ${ }^{373}$ In contrast, under the proposed reasonableness test an employer would escape liability altogether if the plaintiff's decision not to use an available mitigating measure is deemed unreasonable. Thus, the application of the tort doctrine of avoidable consequences in the context of the $\mathrm{ADA}$ will result in much more severe consequences for plaintiffs. Given that the ADA is a "broad remedial statute" ${ }^{374}$ with the goal of eliminating discrimination against individuals with disabilities, ${ }^{375}$ it seems inappropriate to permit courts to deny liability based on standards developed in a damages context. ${ }^{376}$ Indeed, the fact that the tort doctrine permits speculation about the plaintiff's hypothetical mitigated state illustrates that the doctrine is ill-suited to be a model for the determination of liability under the ADA.

\section{c. Line-drawing Problems and the Failure of "Easy" Cases to Justify the Proposed Rule}

The proposed reasonableness test and its associated personalresponsibility rationale has an intuitive appeal, especially with regard to simple external corrective devices that are widely used and reliably

373. STEIN, supra note 303 , at $\$ 18: 9$. The plaintiff still may recover some damages to compensate for injuries that resulted from the defendant's tort, but the plaintiff loses the portion of the recovery that the trier of fact believes resulted from the decision not to use mitigating measures. Id.

374. Arnold v. United Parcel Serv., Inc., 136 F.3d 854, 861 (1st Cir. 1998) (citing Penny v. United Parcel Serv., Inc., 128 F.3d 408, 414 (6th Cir. 1997)).

375. 42 U.S.C. $\$ 12101(b)(1)(1994)$.

376. One district court's discussion of the remedial provisions of Title II of the ADA has suggested that a plaintiff's refusal to use mitigating measures is not relevant to the issue of liability but that it can affect the remedy. Capizzi v. County of Placer emphasized that Title II of the ADA provides that "[t]he remedies, procedures, and rights set forth in section 794a of Title 29 shall be the remedies, procedures, and rights this subchapter provides to any person alleging discrimination on the basis of disability in violation of section 12132 of this title." 135 F. Supp. 2d 1105, 1112 (E.D. Cal. 2001) (quoting $\$ 12133$ of Title II of the ADA). Section 794a, in turn, provides that "[i]n fashioning an equitable or affirmative action remedy ..., a court may take into account the reasonableness of the cost of any necessary work place accommodation, and the availability of alternatives therefore or other appropriate relief to achieve an equitable and appropriate remedy." 29 U.S.C. $\$ 794 a$ (2000). According to the Capizzi court, this provision demonstrates that the failure to mitigate does not defeat a plaintiff's ADA claim but that it might affect the damages awarded once liability is established. Capizzi, $135 \mathrm{~F}$. Supp. $2 \mathrm{~d}$ at 1113. A comprehensive analysis of the view that Title II permits the amount of an ADA plaintiff's damages to be reduced because she did not use mitigating measures is beyond the scope of this Comment. However, it should be noted that the language of section 794 does not refer explicitly to the failure to use mitigating measures, and therefore, the plain language of the clause is ambiguous. Additional evidence is required to support the assertion of the Capizzi court. 
effective, such as eyeglasses or a hearing aid. For example, at first glance it may seem unreasonable for an employer to be required to accommodate a hearing impairment that could be sufficiently improved with a hearing aid. Several factors may influence this perception. In contrast to invasive measures like surgery, which often require the plaintiff to accept some risk without any guarantee of success, an individual can determine if a hearing aid will be effective without any great risk. Further, compared with mitigating measures like medication, which have the potential to affect the employee at work and at home, a hearing aid does not necessarily implicate larger quality-of-life issues since its use can be limited to work hours. With this information in mind, it seems natural to ask why Key's proposal cannot be implemented in this type of "easy" case.

As the facts of Finical v. Collections Unlimited, Inc. illustrated, ${ }^{377}$ the hearing aid example is subject to line-drawing problems similar to those that arise in cases involving mental illness, medication, or surgery. Hearing aids often are uncomfortable, and adjusting to a hearing aid is a gradual process. ${ }^{378}$ In addition, a hearing aid may make the user's own voice sound too loud, and this problem may not be correctable. ${ }^{379}$ Further, a hearing aid may "whistle" at times, potentially causing embarrassment to its user. ${ }^{380}$ These facts suggest that courts may struggle to evaluate the "reasonableness" of an individual's decision not to wear a hearing aid based on discomfort or embarrassment.

Another type of supposedly "easy" case that presents difficult linedrawing problems for Key's reasonableness analysis involves the situation where a plaintiff's nonmitigation is irrational but not necessarily abnormal. As discussed in Part II, empirical evidence has demonstrated that patient noncompliance with prescribed treatment regimens is widespread. ${ }^{381}$ One might argue that empirical evidence of seemingly irrational noncompliance with a particular prescribed treatment by a large percentage of patients makes an individual plaintiff's noncompliance more reasonable.

In addition to these line-drawing problems, it should be noted that many of the supposed "easy" nonmitigation cases will never reach the courts. For example, if the severely myopic Sutton sisters had decided to forgo corrective lenses to meet the ADA's disability definition, their impaired vision would have rendered them unqualified for the airline pilot

377. 65 F. Supp. 2d 1032 (D. Ariz. 1999) (conceming plaintiff who stopped using hearing aid because it registered background noise that annoyed her); see supra notes 165-71 and accompanying text for a discussion of Finical.

378. See National Institute of Health, Hearing Aids, at http://www.medem.com/ MedLB/articleslb.cfm?sub_cat=198 (1999) (last visited May 20, 2002) (on file with author).

379. Id.

380. Id.

381. See supra text accompanying notes 201-04. 
positions that they desired. ${ }^{382}$ Thus, individuals who will not be qualified for their desired jobs when they do not use mitigating measures will have no incentive to declime mitigating measures to receive $\mathrm{ADA}$ protection.

The examples above illustrate that courts will likely encounter very few "easy" cases. Either such cases will actually involve difficult linedrawing issues, and therefore they will not be "easy," or they will not arise because the nonuse of a mitigating measure would render the employee unqualified. Such cases are also unlikely to arise because the day-to-day difficulties of living with a disability create powerful mcentives to use mitigating measures. Rational people will usually choose to mitigate their impairments because the disadvantages of living with an impairment that substantially limits a major life activity are far greater than the cost of undertaking such measures, even where mitigation removes ADA coverage. ${ }^{383}$ Thus, although there may be some instances in which the cost of living with an impairment is low and the benefit of obtaining a reasonable accommodation for it is high, ${ }^{384} \mathrm{ADA}$ coverage of nonmitigating individuals who could easily mitigate their impairments will be the rare exception. Further, such slight overinclusion ${ }^{385}$ is arguably a necessary $\cos ^{386}$ that the statutory scheme must tolerate to achieve the statute's broad goals. Indeed, there is simply no evidence that the "problem" solved by the proposed reasonableness test is siguificant enough to justify the doctrinal leap it entails or the highly fact-specific inquiries it would require courts to perform.

\section{CONCLUSION}

There is no legal justification for denying ADA protection to individuals who do not use available mitigating measures. First and foremost, such a restriction cannot be supported by the statute's language or structure. In addition, Congress has already protected the interests of employers by limiting the protected class to "qualified individuals with a disability," and by providing exceptions for undue hardship, direct threat, and misconduct stemming from drug or alcohol use. Finally, when courts deny an ADA plaintiff's claim because the plaintiff did not use mitigating measures, they are engaging in the type of speculation that the Supreme Court has said is contrary to the individualized inquiry commanded by the

382. See Sutton v. United Air Lines, 1nc., 527 U.S. 471, 475-76 (1999) (noting that without corrective lenses, each of the plaintiffs could not conduct activities such as driving, watching television, or shopping in public).

383. See Harris, supra note 267 , at $600-01$.

384. See id. at 608 n. 83 .

385. Such overinclusion has been tolerated in other contexts, including the administration of disability benefits by the Social Security Administration. For a discussion, see Cleveland v. Policy Mgmt. Sys. Corp., 526 U.S. 795, 803-05 (1999).

386. Prior to Sutton, another commentator made a similar arguinent in the context of whether individuals with controlled impairments are "disabled" within the meaning of the statute. See Harris, supra note 267 , at 596. 
statute. Thus, courts cannot deny ADA protection based on a plaintiff's nonuse of available mitigating measures without threatening the integrity and coherence of the ADA.

In addition, a reasonableness rule denying $\mathrm{ADA}$ protection based on an individual's nonuse of mitigating measures is nnworkable. The prevalence of patient noncompliance with treatment regimens and the subjective, personal nature of any medical decision will lead to difficult line-drawing problems and frequent value judgments, thereby undermining the ADA's goal of providing "clear, strong, consistent, enforceable standards"387 and rendering courts vulnerable to their own insidious "stereotypic assumptions." ${ }^{388}$ In short, a rule that permits courts to evaluate the reasonableness of an ADA plaintiff's decision not to use mitigating measures threatens to subject disabled individuals to a new form of discrimination: discrimination by a justice system that may itself be subject to the misperceptions and insensitivities that historically have relegated disabled individuals to a position of social, political, and economic powerlessness. 